\title{
IISES
}

Scipno tor a changing words

(1)

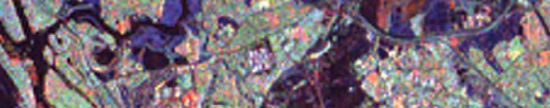

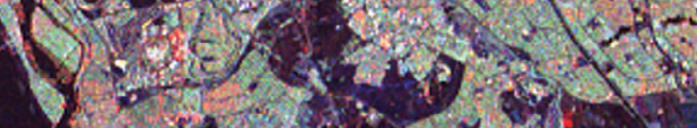

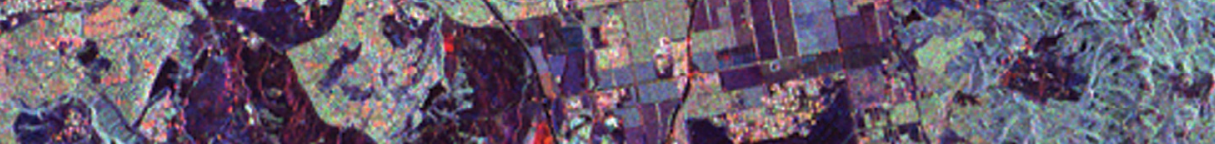

\section{Modeling of Selenium for the San Diego Creek Watershed and Newport Bay, California}
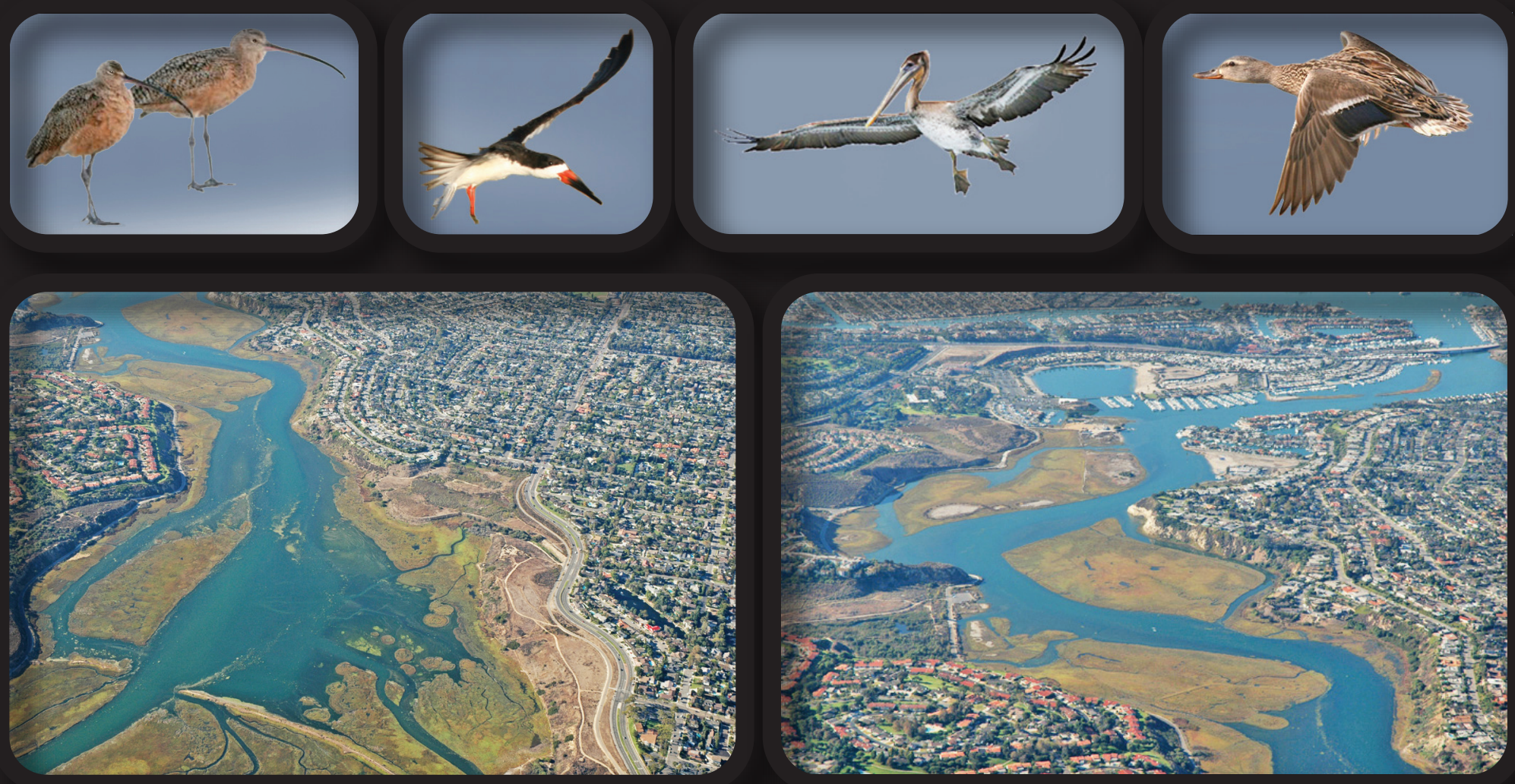

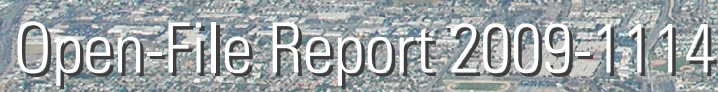

U.S. Department of this literior

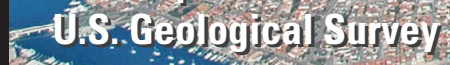

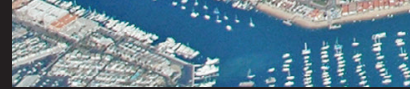


Cover Photos: In order from top, space radar image of Orange County, California, NASA, 2006 [http://visibleearth.nasa.gov]; birds: curlew, skimmer, pelican, and mallard; Upper Newport Bay Ecological Reserve; middle portion of Newport Bay, Lower Newport Bay, California State University, Long Beach, College of Natural Science and Mathematics [http://www.cnsm.csulb.edu].

Cover art by Jeanne DiLeo, USGS, Menlo Park, Calif. 


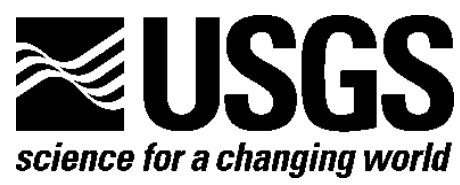

\section{Modeling of Selenium for the San Diego Creek Watershed and Newport Bay, California}

By Theresa S. Presser and Samuel N. Luoma

Open-File Report 2009-1114

U.S. Department of the Interior

U.S. Geological Survey 


\title{
U.S. Department of the Interior \\ KEN SALAZAR, Secretary
}

\author{
U.S. Geological Survey \\ Suzette M. Kimball, Acting Director
}

U.S. Geological Survey, Reston, Virginia 2009

For product and ordering information:

World Wide Web: http://www.usgs.gov/pubprod

Telephone: 1-888-ASK-USGS

For more information on the USGS-the Federal source for science about the Earth, its natural and living resources, natural hazards, and the environment:

World Wide Web: http://www.usgs.gov

Telephone: 1-888-ASK-USGS

Suggested citation:

Presser, T.S., and Luoma, S.N., 2009, Modeling of selenium for the San Diego Creek watershed and Newport Bay, California: U.S. Geological Survey Open-File Report 2009-1114, 48 p.

[http://pubs.usgs.gov/of/2009/1114/].

Any use of trade, product, or firm names is for descriptive purposes only and does not imply endorsement by the U.S. Government.

Although this report is in the public domain, permission must be secured from the individual copyright owners to reproduce any copyright the material contained within this report. 


\section{Contents}

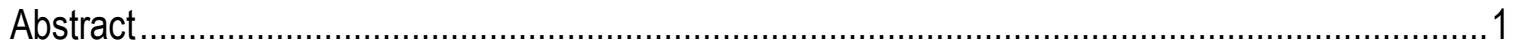

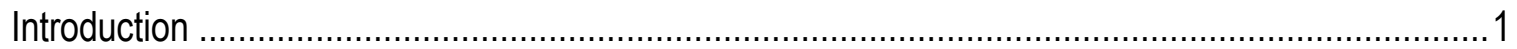

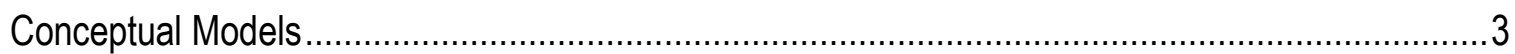

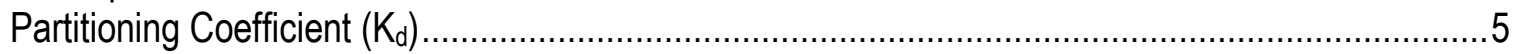

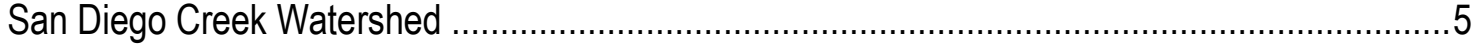

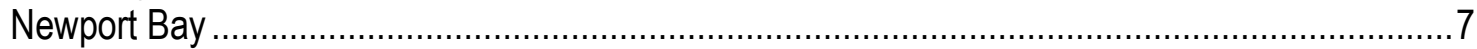

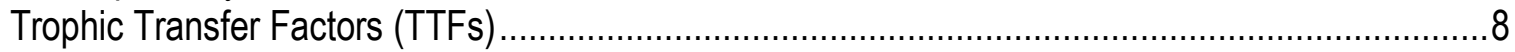

Invertebrates

Fish

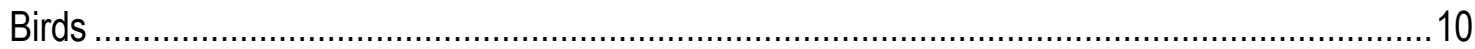

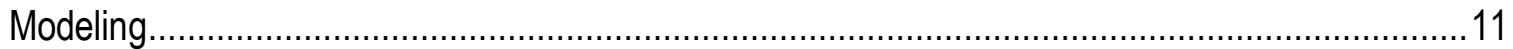

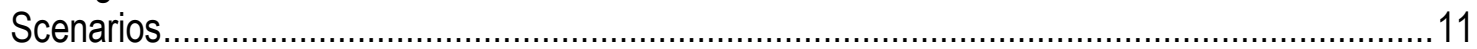

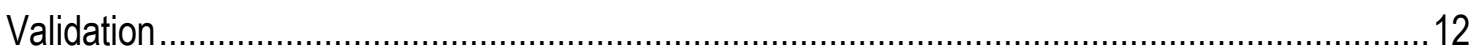

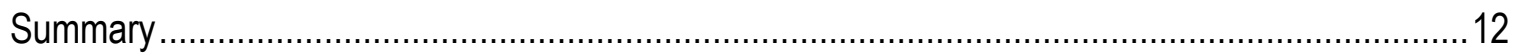

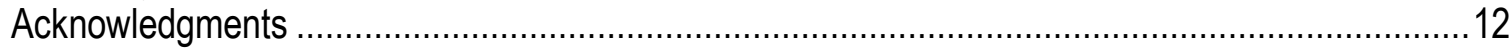

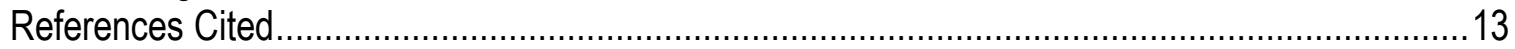

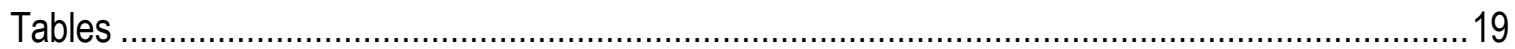

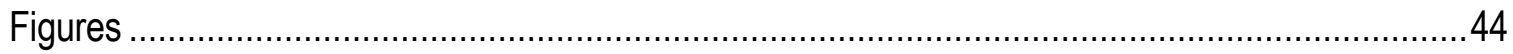




\section{Figures}

Figure 1. Schematic of San Diego Creek watershed and Newport Bay. The Upper Newport Bay Ecological Reserve is shown.

Figure 2. Conceptual model for the San Diego Creek watershed illustrating linked factors that determine the effects of Se on ecosystems.

Figure 3. Conceptual model for the upper Newport Bay illustrating linked factors that determine the effects of Se on ecosystems.

Figure 4. Conceptual model for the lower Newport Bay illustrating linked factors that determine the effects of Se on ecosystems.

Figure 5. Extrapolation of dissolved Se at $15.1 \mathrm{ppt}$ to $0 \mathrm{ppt}$. Data from transect of the upper Newport Bay from the mouth of San Diego Creek into the upper bay (CH2MHILL, 2008).

\section{Tables}

Table 1. Total water-column Se concentrations and Se speciation for the San Diego Creek watershed.

Table 2a. Dissolved or total water-column Se concentrations; Se concentrations in bed sediment and algae; and calculated Kds for the San Diego Creek watershed (freshwater sites)..... 20

Table 2b. Statistics for calculated $K_{d} s$ based on table 2a data.

Table 3. Dissolved water-column Se concentrations and speciation for the Newport Bay estuary.

Table 4. Water-column and suspended particulate Se concentrations in Upper Newport Bay in a transect from the near the mouth of San Diego Creek into the upper bay to salinities of 33.1 ppt.

Table 5. Water-column and sediment Se concentrations and calculated $K_{d} S$ in a gradient from landward to seaward in Newport Bay.....

Table 6. Experimental data for invertebrate physiological factors and calculated kinetic TTFs for invertebrates.

Table 7. Field-derived TTFs for invertebrates from field datasets (temporally and spatially matched data-pairs), with experimentally derived TTFs given for comparison

Table 8. Invertebrate Se concentrations for the San Diego Creek watershed.............................. 25

Table 9. Invertebrate Se concentrations for Newport Bay......................................................... 25

Table 10. Selected particulate Se concentration and a comparison of calculated invertebrate TTFs for the San Diego Creek watershed and invertebrate TTF derived from the literature............ 26

Table 11. Experimentally or field derived TTFs for fish ............................................................. 27

Table 12. Fish Se concentrations for the San Diego Creek watershed. ........................................ 28

Table 13. Invertebrate and fish Se concentrations for San Diego Creek watershed and derivation of watershed-specific TTFs for fish.

Table 14. Invertebrate and fish Se concentrations for Newport Bay and derivation of bayspecific TTFs for fish.

Table 15. Mean and ranges for bird egg Se concentrations for the San Diego Creek

Table 16. Mean and ranges for bird egg Se concentrations for Upper Newport Bay 
Table 17. Calculated TTFs from laboratory mallard studies; the endpoint is reduced hatchability in eggs (see Ohlendorf, 2003 for complete dataset).

Table 18. Modeled Se exposure for the San Diego Creek watershed and Newport Bay................. 32

Table 19. Modeled Se exposure for the San Diego Creek watershed and Newport Bay. ............... 33

Table 20. Modeled Se exposure for the San Diego Creek watershed and Newport Bay................. 34

Table 21. Generalized modeled Se exposure scenarios for the watershed based on protection for fish.

Table 22. Generalized modeled exposure scenarios for the watershed based on protection of birds.

Table 23. Model validation for Newport Bay showing predicted and observed fish Se concentrations.

Table 24. Model validation for bay showing (1) predicted and observed fish Se concentrations and (2) predicted and observed bird egg Se concentrations.

Table 25. Model validation for bay showing predicted and observed bird egg Se concentrations.

Table 26. Model validation for watershed showing (1) predicted and observed invertebrate Se concentrations and (2) predicted and observed bird egg Se concentrations.

Table 27. Model validation for watershed showing (1) predicted and observed fish Se concentrations and (2) predicted and observed bird egg Se concentrations.

Table 28. Model validation for watershed showing predicted and observed bird egg Se concentrations. 


\title{
Modeling of Selenium for the San Diego Creek Watershed and Newport Bay, California
}

\author{
By Theresa S. Presser and Samuel N. Luoma
}

\begin{abstract}
The San Diego Creek watershed and Newport Bay in southern California are contaminated with selenium ( $\mathrm{Se}$ ) as a result of groundwater associated with urban development overlying a historical wetland, the Swamp of the Frogs. The primary Se source is drainage from surrounding seleniferous marine sedimentary formations. An ecosystem-scale model was employed as a tool to assist development of a site-specific Se objective for the region. The model visualizes outcomes of different exposure scenarios in terms of bioaccumulation in predators using partitioning coefficients, trophic transfer factors, and site-specific data for food-web inhabitants and particulate phases. Predicted Se concentrations agreed well with field observations, validating the use of the model as realistic tool for testing exposure scenarios. Using the fish tissue and bird egg guidelines suggested by regulatory agencies, allowable water concentrations were determined for different conditions and locations in the watershed and the bay. The model thus facilitated development of a site-specific Se objective that was locally relevant and provided a basis for step-by-step implementation of source control.

\section{Introduction}

Understanding the biotransfer of selenium (Se) is essential for evaluating the effects of Se on ecosystem resources. The linked approach presented in the San Francisco Bay-Delta Selenium Model (Presser and Luoma, 2006) considers progressive modeling of Se through water-column loads, concentrations, and speciation; particulate matter transformation and bioavailability; the biodynamics of bioaccumulation in prey; and trophic transfer to predators. This approach can conceptualize and model Se exposure through site-specific food webs and determine the vulnerability of predator species in an ecosystem. This approach also can be used to generate forecasts of how Se moves through a watershed and estuary based on selected management and regulatory options.
\end{abstract}


Groundwater- and wastewater-related discharges of Se within the San Diego Creek watershed have the potential to adversely affect surface waters and, hence, habitats within the watershed and Newport Bay (fig. 1) (U.S. Environmental Protection Agency, 2002). In 2004, the California Santa Ana Regional Water Quality Control Board issued a revised National Pollutant Discharge Elimination System permit regulating groundwater-related discharges in the watershed (California Santa Ana Regional Water Quality Control Board, 2004). This specific revised regulatory approach addressed (1) the presence of Se and nitrogen and (2) the ability to comply with established Total Maximum Daily Load requirements for impaired water bodies (that is, San Diego Creek and Newport Bay) (U.S. Environmental Protection Agency, 2002). This action initiated an alternative compliance approach allowing stakeholders to participate in Work Groups to develop and implement a comprehensive Work Plan to address Se and nitrogen. This process included Federal agencies (U.S. Environmental Protection Agency, U.S. Fish and Wildlife, U.S. Geological Survey), State and County agencies (California State and Regional Boards; California Department of Fish and Game; County of Orange), and three consulting groups (CH2M Hill, RBF Consulting, and Larry Walker Associates) working cooperatively as the Resource and Regulatory Agency Group with the regulated community to develop a site-specific Se objective to integrate into a watershed scale management strategy for Se (California County of Orange, 2006a; Larry Walker Associates and CH2M Hill, 2007; California Nitrogen and Selenium Management Program, 2006a). A primary task included in the development of the site-specific Se objective was the adaptation of the San Francisco Bay-Delta Selenium Model to the San Diego Creek watershed and Newport Bay. The modeling would translate selected tissue guidelines for predators (that is, whole-body fish tissue and bird egg tissue) to dissolved Se concentrations at chosen sites in the watershed. The dissolved Se concentrations would then facilitate calculation of Total Maximum Daily Load Se requirements for the watershed (U.S. Environmental Protection Agency, 2002).

This report is supplemental to the larger effort of justifying, deriving, and implementing a site-specific Se objective for San Diego Creek watershed and Newport Bay (California Santa Ana Regional Water Quality Control Board, 2004). In that regard, this report is written mainly for a specific audience that has considerable knowledge of the watershed and has participated in Resource and Regulatory Agency Group and Work Group meetings from 2007 to 2009. In addition to this project report, a report is planned that further details and justifies the approach for ecosystem-scale modeling of Se.

This report (1) designs conceptual models for the San Diego Creek watershed and Newport Bay; (2) derives and justifies partitioning coefficients $\left(\mathrm{K}_{\mathrm{d}} \mathrm{s}\right)$ and trophic transfer factors (TTFs) used in modeling of the watershed and bay; (3) models different food-web scenarios to elucidate Se exposure within the watershed and bay; and (4) compares predicted Se concentrations to modeled Se concentrations (that is, validation). The work presented here shows the nature of a cooperative iterative process resulting in sitespecific regulation and the evolution of our modeling effort. During this time, additional field data became available, data gaps were addressed, feedback was given, guidelines were developed, and revised exposure scenarios were completed. Thus, this report, in addition to illustrating modeling of Se for the watershed and bay, serves as a record to support decision-making within the larger group of resource and regulating agencies. 
From a scientific perspective, this watershed-scale project illustrates the importance of ecosystem knowledge, especially ecology, for successful Se modeling.

\section{Conceptual Models}

A generalized schematic of the San Diego Creek watershed and Newport Bay is presented in Figure 1. The watershed is in an urban setting that is intensively developed (93 percent urban uses; 7 percent agricultural uses, including plant nurseries). Newport Bay is an important southern California estuary that is an ecological reserve in the upper portion and a developed marina for recreational boating and fishing in the lower portion. Figure 1 shows the boundaries of historical marshes (Swamp of the Frogs and an ephemeral lake), and these areas overlay aquifers containing the most elevated Se concentrations (Hibbs and Lee, 2000; Meixner and others, 2004). Geologic Se sources are implicated for the watershed including the surrounding Monterey Formation (Piper and Isaacs, 1994). Ninety-six percent of Se loading is estimated to be from groundwater sources in the watershed (California Nitrogen and Selenium Management Program, 2006b; 2009). Drains and drainage channels are important parts of the hydrology of the watershed because of the presence of a high ground water table (Hibbs and Lee, 2000; Meixner and others, 2004).

Sites for modeling (Larry Walker Associates Inc. and CH2M Hill, 2007) within the San Diego Creek watershed and Newport Bay include:

- marsh drains (drains within the area historically designated as the Swamp of the Frogs);

- non-marsh drains (drains outside the area of the historical swamp);

- upper and lower San Diego Creek (SDC);

- upper and lower Peters Canyon Wash (PCW);

- Irvine Ranch Water District (IRWD) off-channel wetlands;

- University of California at Irvine (UCI) off-channel wetlands; and

- Upper and Lower Newport Bay.

Some data exist for other freshwater drainages to the bay [for example, Santa Ana Delhi Channel (SADC), Big Canyon Wash], but these sites are not included in the final exposure analysis.

Aquatic habitat categories within the area are: riparian channels and pools; control basins; freshwater wetlands; salt marsh; tidal mudflat; estuarine open-water; and marine openwater. The quality of the habitats varies, as does the potential for Se interaction (for example, low habitat value and high Se exposure in some marsh drains). Many of the habitat components are highly engineered and managed to serve several purposes, including treatment for nitrogen and phosphorus and sediment control (for example, inchannel or off-channel wetlands; detention basins in lower San Diego Creek).

The Upper Newport Bay Ecological Reserve and the bay itself (fig. 1) are important stopovers for birds on the Pacific Flyway. Threatened or endangered bird species include the light-footed clapper rail (Rallus longirostris levipes), California brown pelican 
(Pelecanus occidentalis californicus), and California least tern (Sterna antillarum browni) (Sutula and others, 2005; Allen and others, 2008). Bird species of concern in California are osprey (Pandion haliaetus), double-crested cormorant (Phalacrocorax auritus), elegant tern (Thalasseus elegans), black skimmer (Rhynchops niger), and California gull (Larus californicus). Forage fish species that serve as food for birds include killifish, goby, juvenile halibut, sculpin, and topsmelt (Allen and others, 2004). Larger predatory fish species include sea basses, halibut, sand bass, croaker, and jacksmelt. Shellfish sampling of bivalves showed 24 species of bivalves, with the lower bay supporting more species (California County of Orange, 2004). However, lack of previously available commercial species has deterred studies to evaluate the suitability of existing bay habitats and water quality for renewal of a shellfish industry. Several organic chemicals, including modern pesticides (diazinon, chlorpyrifos) and legacy pesticides (DDT, Chlordane), as well as heavy metals (cadmium, copper, lead, zinc, and mercury) also are of concern in the watershed and bay and may have affected the status of specific food webs and their inhabitants (U.S. Environmental Protection Agency, 2002).

Conceptual Se models for the San Diego Creek watershed and Newport Bay are based on the approach of Presser and Luoma (2006) (figs. 2-4). Important components of food webs identified from site-specific monitoring data (CH2M Hill, 2008a) for the freshwater portions of the watershed are:

- invertebrates: aquatic insect, crayfish, clam, snail, worm, leech.

- fish: minnow, sunfish, carp shiner, crappie, catfish, bass, mosquitofish.

- birds: avocet, stilt, rail, killdeer, coot, mallard, grebe.

Important components of food webs identified from site-specific monitoring data $(\mathrm{CH} 2 \mathrm{M}$ Hill, 2008a) for the estuarine and marine portions of bay are:

- invertebrates: amphipod, isopod, clam, mussel, crab, snail.

- fish: mullet, killifish, goby, anchovy, sandbass, turbot, halibut, sculpin, perch, topsmelt.

- birds: avocet, stilt, rail, killdeer, tern, skimmer.

Some species not represented in the collected species (for example, polychaetes) were modeled because of implications for past and future food webs.

Datasets compiled for modeling are food-web-specific and include Se data for the water column (dissolved or total Se); particulate phases; invertebrates; fish (whole-body); birds (egg); and, when available, dissolved Se speciation and salinity (CH2M Hill, 2008a).

These datasets are limited to data that are temporally and spatially matched [that is, datasets gathered across media (water, particulate material, invertebrates, fish and/or bird tissue) and during a constrained time period]. Summaries of the data are presented in this report, with extensive documentation available in the spreadsheet datasets that are part of the site-specific Se objective process (CH2M Hill, 2008a). Data are sorted according to seasonal conditions (wet season, November through April, and dry season, May through October). However, the small number of data for prey and predators precluded conclusions based on season. All solids data are given in dry weight (dw). 


\section{Partitioning Coefficient $\left(K_{d}\right)$}

\section{San Diego Creek Watershed}

Partitioning of Se between water and particulate material is a dynamic biogeochemical process. Because of the biology involved, it is complex to model (that is, geochemical modeling misses major biological processes). At any point in time and space, Se partitioning can be described by a distribution coefficient, which is the ratio

$$
\mathrm{K}_{\mathrm{d}}=\text { Se concentrations in particulate }(\mu \mathrm{g} / \mathrm{kg} \mathrm{dw}) / \text { Se concentrations in water }(\mu \mathrm{g} / \mathrm{L}) \text {. }
$$

Note that particulate Se concentrations are usually expressed as $\mu \mathrm{g} / \mathrm{g} \mathrm{dw}$. These units must be converted to $\mu \mathrm{g} / \mathrm{kg}$ dw to make the particulate concentrations comparable to water concentrations. Presser and Luoma (2006) explained this coefficient in detail and presented data from the literature showing the wide range of distribution coefficients $\left(K_{d}\right.$ 's) that occurred in different environments. They recognized that the use of $K_{d}$ is an operational, descriptive choice for characterizing Se dynamics in an environment. As a practical measure $K_{d}$ is very useful, but there are limits to its interpretation in terms of describing and quantifying phase transformation processes (Presser and Luoma, 2006).

A major factor determining the magnitude of the partitioning coefficient is Se speciation in the water column (Presser and Luoma, 2006). Dissolved Se can exist as selenate, selenite, and organo-Se. Selenium speciation also differs in nature with the character of the input to a water body and the residence time in the water body. For example, Se often enters a stream (for example, San Diego Creek) as selenate. If that stream flows into a wetland and is retained in a wetland (that is, in-stream water becomes off-stream water) with sufficient residence time, then recycling of Se may occur. During recycling, some selenate is taken up by bacteria and/or plants and converted to selenite and organo-Se. These reduced species then are released back to the water as these organisms die and decay. The more recycling, the more selenite and organo-Se are produced. Neither of the latter forms can be re-oxidized to selenate; that reaction takes hundreds of years (Cutter and Bruland, 1984). Therefore, the net outcome of recycling in a watershed is a gradual buildup of selenite and organo-Se in the water. This process is evidenced in the San Diego Creek watershed by a small increase in selenite ( 21 to 25 percent) toward the downstream end of the system, 39-100 percent selenite in watershed wetlands, and as much as 78 percent selenite in the estuary (table 1).

Reactions between particles and dissolved Se are dominated by biological uptake into bacteria, plants, and their decaying debris termed detritus. Selenate is the least reactive of the three forms of dissolved Se in generating particulate material. Thus, if selenate is the only form of Se, then the $\mathrm{K}_{\mathrm{d}}$ tends to be low. This condition reflects low Se concentrations on particulate material compared to Se concentrations in the water column. As selenite concentrations increase (even if that increase is small) the ratio begins to increase. In the case here, as the San Diego Creek watershed changes from freshwater to the saline water of the estuary and bay, residence time increases, recycling increases, and eventually the ratio of particulate to dissolved Se can be extremely high as Se is stripped from the water column with increasing effectiveness. 
Presser and Luoma (2006) discussed several studies that supported the link between speciation and partitioning coefficient; however, several additional studies are included in this report. Calculations using data from laboratory microcosms and experimental ponds show speciation-specific $K_{d} \mathrm{~S}$ of 140-493 for selenate; 720-2,800 when an elevated proportion of selenite exists; and 12,197-36,300 for 100-percent dissolved selenomethionine uptake into algae or periphyon (Besser and others, 1989; Graham and others, 1992; Kiffney and Knight, 1990). These ranges are consistent with the general ranges for $\mathrm{K}_{\mathrm{d}}$ used by Presser and Luoma (2006) for modeling of the San Francisco Bay-Delta Estuary when they developed scenarios based on several possible fates for Se. These ranges also are consistent with the full range for Se in the San Diego Creek watershed and Newport Bay.

The $\mathrm{K}_{\mathrm{d}}$ also can be influenced by the type of material in the sediment, although to a lesser degree than by speciation. For example, field data for Luscar Creek in Alberta, Canada, show a hierarchy of Se concentrations: $2.4 \mu \mathrm{g} / \mathrm{g} \mathrm{dw}$ in sediment, $3.2 \mu \mathrm{g} / \mathrm{g} \mathrm{dw}$ in biofilm, and $5.5 \mu \mathrm{g} / \mathrm{g} \mathrm{dw}$ for filamentous algae (Casey, 2005). Using these concentrations with a field-measured dissolved Se concentration of $10.7 \mu \mathrm{g} / \mathrm{L}$ yields $\mathrm{K}_{\mathrm{d}} \mathrm{s}$ of 224, 299, and 514 respectively, with an average $\mathrm{K}_{\mathrm{d}}$ of 346 . Similarly, field data for a slough tributary to the San Joaquin River, California, show a hierarchy of Se concentrations: $0.47 \mu \mathrm{g} / \mathrm{g} \mathrm{dw}$ in sediment, $2.4 \mu \mathrm{g} / \mathrm{g} \mathrm{dw}$ in algae, and $7.9 \mu \mathrm{g} / \mathrm{g} \mathrm{dw}$ in detritus (Saiki and others, 1993). Using these concentrations with a field-measured dissolved Se concentration of $13 \mu \mathrm{g} / \mathrm{L}$ yields $K_{d} s$ of 36, 185, and 608 respectively, with an average $K_{d}$ of 276.

Interpretation of particulate Se concentrations should take into consideration, where possible, the nature of the particulate material. Bed sediments are the least desirable choice for calculating $K_{d}$, especially if the sediments vary from sand to fine-grained material among the samples. Sandy sediments dilute concentrations with a high mass of inorganic material and may yield $\mathrm{K}_{\mathrm{d}} \mathrm{s}$ that are anomalously low. On the other hand, bed sediments samples are the most traditional type of sample to collect; and Se concentrations in bed sediment are commonly all that are available. In that case, these data are used for determination of $\mathrm{K}_{\mathrm{d}}$. Further operational choices include comparison of one consistent type of material among locations or comparison of an average of the different types of materials (that is, all relevant particulate phases). In practical terms however, modelers usually have to work with the particulate Se data that are available and try to find ways to both minimize the influences caused by particle type and capture the influences of changes in speciation. This is the approach taken below.

Several approaches are possible in choosing a $\mathrm{K}_{d}(\mathrm{~s})$ for the San Diego Creek watershed. The dataset for Se concentrations in the water column is extensive, but a smaller dataset exists for particulate Se concentrations (CH2M Hill, 2008a). Table 1 is a summary of total water-column Se concentrations and the percentages of dissolved selenite for the watershed during the dry season. The datasets for water and sediment data pairs were more numerous for the dry season than for the wet season. Table $2 \mathrm{a}$ shows a summary of available Se concentrations for bed sediment and algae samples collected in the same place and at the same time as the water-column samples (that is, matched samples). The 75 th percentile values for all data collected at each of the sites also are shown. Use of a 75 th percentile value was chosen by the Resource and Regulatory Agency Group as a 
useful statistical representation for the data. The location-specific $\mathrm{K}_{\mathrm{d}} \mathrm{s}$ are calculated from these data and are shown in table 2a. Table $2 \mathrm{a}$ was assembled at the request of the Resource and Regulatory Agency Group for the purpose of illustrating the basis for decisions (and the uncertainty around those decisions) concerning $K_{d} s$ for the watershed. Table 2a is complex, but the compilation is intended to show all the available data and the limitations of the datasets for particular sites.

The $K_{d}$ s for different environments in the San Diego Creek watershed vary from $<100$ to a maximum of 938, averaging 241 (table $2 \mathrm{~b}$ ). The UCI marsh is a consistent exception from the rest of the watershed, with $\mathrm{K}_{\mathrm{d}} \mathrm{s}$ from 656 - 939, averaging 791. Excluding UCI marsh, the range is 19 to 444 , averaging 168 across the entire creek. Thus, the variability (based on a coefficient of variation) in the $\mathrm{K}_{\mathrm{d}}$ in this area is about twofold. The 75th percentile for all values (excluding UCI marsh) is 238. The type of particulate materials used (for example, sediment or algae) has a small influence on $\mathrm{K}_{\mathrm{d}}$ in this dataset. Differences are not large between $K_{d} s$ determined from matched data-pairs (particulate and water samples collected in the same place and at the same time) and $\mathrm{K}_{d} \mathrm{~S}$ calculated from the 75th percentile of all available water and sediment data (where enough sediment data are available to do that calculation). The greatest differences in Kds, however, are due to the inherent spatial variability in the data (table 2).

Choices for $\mathrm{K}_{\mathrm{d}}$ used in freshwater modeling (shown later in tables 18-22) are:

1. A choice for $\mathrm{K}_{\mathrm{d}}$ of approximately 200 would illustrate a representative freshwater average scenario. This choice of $\mathrm{K}_{\mathrm{d}}$ reflects the mean (168) and 75th percentile (238) $\mathrm{K}_{\mathrm{d}} \mathrm{s}$ for the San Diego Creek watershed. Predictions using this $\mathrm{K}_{\mathrm{d}}$ would represent water-column Se concentrations if conditions in the watershed stayed much like they are now.

2. A more environmentally conservative approach is illustrated using the 75 th percentile of all $\mathrm{K}_{d} \mathrm{~S}$ (approximately 400). Predictions using this $\mathrm{K}_{\mathrm{d}}$ would represent water-column Se concentration if conditions in the watershed change, for example, to allow more recycling. Use of this environmentally conservative $\mathrm{K}_{\mathrm{d}}$ would be desirable to assure the greatest likelihood of remaining below fishtissue guidelines within the entire watershed.

3. An alternative approach would be to assume that any areas that behaved like the UCI wetlands must be protected. In that case, a $\mathrm{K}_{\mathrm{d}}$ of 800 could be used in modeling.

\section{Newport Bay}

Table 3 shows a summary of dissolved Se concentrations for Newport Bay as a function of salinity (parts per thousand, ppt) and the percentage of selenite as a fraction of the dissolved Se. Concentrations decline dramatically between the mouth of San Diego Creek and the lower bay. Dissolved Se concentration data in a transect from near the mouth of the estuary at San Diego Creek into Upper Newport Bay (table 4) were used to predict the Se concentration at the mouth of the estuary (at 0 ppt salinity) (fig. 5; table 3). The extrapolation of the dissolved Se concentration from a salinity of $15.1 \mathrm{ppt}$ to a salinity of 
$0 \mathrm{ppt}$ is based on Se being conservative (that is, no loss into other phases of the environment). Table 4 also shows the results of Se analysis of suspended particulate samples for the upper bay taken at the same time as the dissolved samples. The $\mathrm{K}_{\mathrm{d}} \mathrm{S}$ calculated from the matched dissolved and particulate Se concentrations increase from 107 in the landward-most sample to as high as 578 and 776 seaward. One choice for a $\mathrm{K}_{\mathrm{d}}$ for modeling the upper bay is the mean of these values: 264. Another alternative is the 75 th percentile value: 353 .

Table 5 shows the mean of 11 samples of dissolved and bed-sediment Se concentrations collected at different harbors of Newport Bay, most of which are in the lower bay. The locations closest to where San Diego Creek enters the upper bay (Newport Dunes and Bayside DeAnza) had the lowest Se concentrations in sediment and the highest dissolved Se concentrations for this dataset. The most enclosed location (Harbor Towers), which is likely to have the poorest circulation and longest residence, had the highest $\mathrm{Se}$ concentrations in sediments and low dissolved Se. These patterns suggest that biogeochemical processes progressively transform Se to particulate forms as the contaminants are transported seaward and residence time allows longer reaction times. The distribution also could reflect some transport seaward of fine-grained sediments from the watershed. Whatever the processes involved, most of the Se coming from the watershed is trapped in these harbors. $\mathrm{K}_{\mathrm{d}} \mathrm{s}$ also increase dramatically in these environments (from approximately 7,000 to 43,000 ). Unfortunately no data are available to track Se concentrations on suspended particulate concentrations in the water column, making it difficult to draw conclusions about how tightly the water-column community of invertebrates, fish, and birds is linked to these contaminated sediments. Modeling for the bay depends on particulate Se data and an assumption that bed-sediment Se concentrations are linked to the Se concentrations in invertebrates, fish, and birds in the system. Choices for estuary and bay modeling shown later employ $\mathrm{K}_{\mathrm{d}} \mathrm{s}$ of $200,1,000$, 10,000 and 20,000 to represent the various conditions from the upper bay to the most isolated harbors.

\section{Trophic Transfer Factors (TTFs)}

Traditional models for aquatic systems attempt to quantify the linkage between Se concentrations in invertebrates, fish, and aquatic birds and those in the environment. The traditional approach was to employ a bioconcentration factor $(\mathrm{BCF})$, which is the ratio between Se accumulated by an organism from water and Se concentrations in the water; or a bioaccumulation factor (BAF), which is the ratio between the concentration accumulated by the animal from all sources (for example, in the field) and the concentration in the water column. It is well recognized that BCFs and BAFs are extremely variable among circumstances and are not constants (McGeer and others, 2003; DeForest and others, 2007). The latter means that both factors can change as Se concentrations change, even if all other conditions are held constant. It is also widely recognized that this approach is not very useful for understanding Se exposures because it skips links among components of food webs (figs. 2-4).

Selenium trophic transfer factors (TTFs), on the other hand, take account of the wellestablished principle that Se is bioaccumulated almost entirely from the food an animal 
eats (Luoma and others, 1992; Presser and Luoma, 2006). In addition, the extent of bioaccumulation (that is, the concentration achieved by the organism) is driven by physiological constants that are specific to each species (Luoma and Rainbow, 2005). Experimental protocols are now well developed for defining those constants. The constants are assimilation efficiency (AE), ingestion rate (IR) and the rate constant that describes Se excretion or loss from the animal $\left(\mathrm{k}_{\mathrm{e}}\right)$. In the absence of rapid growth, the species-specific potential for an organism to bioaccumulate Se is

$$
\mathrm{TTF}=[(\mathrm{AE})(\mathrm{IR})] / \mathrm{k}_{\mathrm{e}}
$$

as defined by Reinfelder and others (1998) and reviewed by Wang (2002). If field data are available, derivation is from matched data-pairs using the equation

$$
\mathrm{TTF}=\mathrm{C}_{\text {animal }} \div \mathrm{C}_{\text {diet }}
$$

\section{Invertebrates}

TTFs from kinetic experiments

Table 6 shows a summary of Se TTFs determined in robust kinetic experiments over the past decade for a variety of marine invertebrate taxa and the freshwater zebra mussel. The clam Corbicula fluminea can exist in both freshwater and marine environments. The table also illustrates the degree of variability among different determinations of TTF. The variability typically reflects the influences of different factors, such as food type and food availability, but also includes some influence from experiment-to-experiment variability. The variability among studies for each species is typically much smaller than the variability among species.

TTFs from field data

Selenium TTFs also can be derived from field data, using the ratio of bioaccumulated Se in the animal versus the concentration of Se in its food. Table 7 shows a summary of TTFs derived for different animal taxa from field studies for which robust data are available. Kinetic TTFs are given where appropriate for comparison. The use of these field data allows us to expand the number of taxa for which TTFs are available for modeling.

\section{TTFs from San Diego Creek}

Some data for Se concentrations in invertebrates are available from both the San Diego Creek habitat and from Newport Bay. Tables 8 and 9 show summaries of available Se concentrations for invertebrates collected in the San Diego Creek watershed and Upper and Lower Newport Bay. One way to verify if data from other locations are appropriate for use in the San Diego Creek situation is to compare TTFs from the small data set available for the local environment with those from elsewhere. Table 10 shows a comparison of the TTFs derived locally with a summary of those derived in tables 6 and 7. The local values, even though based upon a limited number of data-pairs in many cases, are comparable to the literature-derived values, verifying that studies in other 
situations are applicable to the local conditions in the San Diego Creek watershed (table 10). From these summaries, choices are possible with regard to which TTFs to use in modeling for major groups of taxa:

- Freshwater:

○ insects in general: 2.8

○ zooplankton: 1.5 (amphipod: 0.6; copepod: 2.05)

○ freshwater clams: 2.7

o freshwater mussels: 6

- Bay

○ deposit-feeding clams: 7.4

○ marine mussels: 6

○ amphipods: 0.6

○ zooplankton: 1.5

○ polychaete worm: 4.5

Although some clams show much higher potential for bioaccumulation, this has not been verified in the field.

\section{Fish}

Table 11 shows a compilation of Se TTFs for fish derived from experimental studies and from sets of matching field data for invertebrates and fish. The average TTF for this set of data is 1.18 and the 75 th percentile is 1.34 . Table 12 shows a summary of available Se concentrations for fish tissue collected in the watershed. Table 13 shows the derivation of site-specific Se TTFs for fish in the watershed based on matched fish and invertebrate data. Fewer data are available for fish than for invertebrates in the watershed. The range of site-specific TTFs is 0.8 to 4.6 , so choosing a Se TTF for fish of 1.1 to 1.2 would be conservative on the basis of local data. Table 14 shows a summary of available Se concentrations for fish tissue collected in the bay and calculated site-specific TTFs based on matched fish and invertebrate data. The range of site-specific TTFs is 0.62 to 1.3. Most modeling scenarios use a default TTF for fish of 1.1 .

\section{Birds}

Tables 15 and 16 show summaries of available Se concentrations for bird eggs collected in the watershed and bay. Table 17 shows the laboratory data used to derive a TTF for birds for modeling. A range of 1.8 to 2.9 is shown. The toxicity endpoint for the experimental studies was reduced hatchability in mallard eggs (Ohlendorf, 2003). A TTF of 1.8, the lowest value derived from this dataset, is chosen for modeling. This choice would represent the least effective bioaccumulative potential derived from the dataset. The choice of 1.8 can be modified as part of exposure scenarios if regulating agencies such as the U.S. Fish and Wildlife Service decide to do so. The TTFs derived from experimental data may be most relevant to resident birds rather than to birds feeding in a larger range of diverse habitats. Another compilation of studies relevant to calculating TTFs for birds concluded that a TTF of 1.4 was appropriate for the watershed $(\mathrm{CH} 2 \mathrm{M}$ HILL, 2008b). 


\section{Modeling}

\section{Scenarios}

Modeling scenarios were constructed throughout the course of the development of a sitespecific Se objective for the San Diego Creek and Newport Bay watershed. The generalized equations (Presser and Luoma, 2006) used for translation of tissue Se guidelines to dissolved Se concentrations are

$$
\begin{gathered}
\mathrm{C}_{\text {water }}=\left(\mathrm{C}_{\text {fish }}\right) \div\left(\mathrm{TTF}_{\text {fish }}\right)\left(\mathrm{TTF}_{\text {invertebrate }}\right) \mathrm{K}_{\mathrm{d}} \\
\mathrm{C}_{\text {water }}=\left(\mathrm{C}_{\text {bird egg }}\right) \div\left(\mathrm{TTF}_{\text {bird }}\right)\left(\mathrm{TTF}_{\text {invertebrate }}\right) \mathrm{K}_{\mathrm{d}}
\end{gathered}
$$

Equations may be modified for more complex food webs by inserting additional TTFs. In addition to modeling scenarios chosen for illustration of specific food-web exposure in the watershed and bay, some modeling conditions were stipulated by those collaborating in the site-specific Se objective process.

A series of exposure scenarios are shown in tables 18-20 (for example, particulate to invertebrate to fish to bird; particulate to invertebrate to bird; particulate to invertebrate to forage fish to predator fish). The scenarios employ a fish-tissue target of $5.0 \mu \mathrm{g} / \mathrm{g}$ wholebody dw or a bird-egg target of $8.0 \mu \mathrm{g} / \mathrm{g}$ whole-egg dw. These targets were chosen as part of the regulatory process of the Resource and Regulatory Agency Group for the San Diego Creek watershed and Newport Bay. The Se TTF used for modeling exposure of fish is 1.1, except for mosquitofish, where a TTF of 2.2 was used. The TTF used for modeling exposure of birds is 1.8. For the watershed, aquatic insects (TTF $=2.8)$ were used as the selected invertebrate on which to base translation for invertebrate-eating fish or birds. Selenium TTFs for invertebrates used in modeling for the mouth of the estuary and the upper and lower bay varied from 2.05 for copepod, 4.5 for polychaete, and 7.4 for clam. Modeled $\mathrm{K}_{\mathrm{d}} \mathrm{S}$ were those derived previously to represent the habitats of the watershed (200-1,000) and bay (200 to 20,000). Tables 21 and 22 show requested generalized exposure scenarios for the watershed based on protecting fish or birds. Results of modeling are shown for varying $\mathrm{K}_{\mathrm{d}} \mathrm{s}$, guidelines for the protection of fish and birds, and the TTFs for birds.

Modeling of the conditions and habitats of the San Diego Creek watershed and Newport Bay shows the importance of (1) wetlands within the watershed and (2) estuary interaction within the lower and upper bays in determining the fate of Se discharged within the watershed. Food-web modeling of the watershed predicts increased Se transfer from the upper watershed through lower San Diego Creek to the lower wetlands. Foodweb modeling of Newport Bay predicts that if predators are limited to feeding on prey from the water column (the current main food webs), then trophic transfer will be less than if transfer is through a food web consisting of benthic predators (restored food webs). 


\section{Validation}

Comparisons were made between predicted concentrations and available observed Se concentrations for invertebrate, fish, and bird species to test the validity of the selected approach and site-specific assumptions for the San Diego Creek watershed and Newport Bay (tables 23-28). In some cases, few data were available for comparison. Predicted Se concentrations were in the range of observed Se concentrations for most modeled cases. Where there were discrepancies, modeling factors were examined and redefined or it was recommended that additional data be collected to confirm modeling expectations.

\section{Summary}

Critical variables to be considered in modeling and protection of a watershed or estuary are (1) Se speciation in the water column, (2) bioavailablity of particulate material as food for invertebrates, and (3) the biodynamics of food ingestion in invertebrates, fish, and birds. Site-specific modeling of Se exposure in prey-predator pairs in the San Diego Creek watershed and Newport Bay illustrates the differences in invertebrate physiology that are propagated to higher trophic levels as a main determinant of exposure and, hence, risk. Modeling of the estuary and bay illustrates that biogeochemical processes progressively transform Se to particulate forms as the contaminants are transported seaward and residence time allows longer reaction times.

A final recommendation of a site-specific Se objective for San Diego Creek watershed and Newport Bay involves more choices than analyzed here. These choices include collaborative resolution of (1) what habitat to protect (the most sensitive part of the watershed or bay; a generalized watershed; individual components of the watershed or bay); (2) what predators and food webs to protect (endangered and threatened species; commercially valuable species; existing abundant species); (3) what parameters to use in modeling (maximums; averages; or 75th percentile); and (4) what type of guideline to adopt (fish or bird tissue; dietary; or water column). An overarching question for those confronted with protection of a watershed/estuary that is affected by a mixture of legacy pollutants, such as the San Diego Creek watershed and Newport Bay, is whether to restore the ecosystem and consider exposure scenarios based on potential future inhabitants of the ecosystems.

\section{Acknowledgments}

We wish to thank Orange County for providing cooperative funding with the U.S. Geological Survey for this project. We also thank participating members of the U.S. Environmental Protection Agency, U.S. Fish and Wildlife Service, the California State Water Resources Control Board, the Santa Ana Regional Water Resources Control Board, the California Department of Fish and Game, CH2M Hill, Larry Walker Associates, and RBF Consultants for their insights and support during this process. We wish to especially thank Christine Arenal of CH2M Hill for the compilation of a comprehensive Se dataset and Jeanne DiLeo of USGS for the illustration of the Se pathway in the watershed and bay. 


\section{References Cited}

Allen, M.J., Diehl, D.W., and Zeng, E.Y., 2004, Bioaccumulation by recreational and forage fish in Newport Bay, California in 2000-2002: Westminster, California, Southern California Coastal Water Research Project, Technical Report 436, 68 p.

Allen, M.J., Mason, A.Z., Gossett, R., Diehl, D.W., Raco-Rands, V., and Schlenk, D., 2008, Assessment of food web transfer of organochlorine compounds and trace metals in fishes (2005-2006) in Newport Bay, California; Final Grant Report, Costa Mesa, California, Southern California Coastal Water Research Project, 81 p.

Alquezar, R., Markich, S.J., and Twining, J.R., 2008, Comparative accumulation of ${ }^{109} \mathrm{Cd}$ and ${ }^{75} \mathrm{Se}$ from water and food by an estuarine fish (Tetractenos glaber): Journal of Environmental Radioactivity, v. 99, no. 1, p. 167-180.

Baines, S.B., Fisher, N.S., and Stewart, R., 2002, Assimilation and retention of selenium and other trace elements from crustacean food by juvenile striped bass (Morone saxitilis): Limnology and Oceanography, v. 47, no. 3, p. 646-655.

Bennett, W.N., Brooks, A.S., and Boraas, M.E., 1986, Selenium uptake and transfer in an aquatic food chain and its effects on fathead minnow larvae: Archives of Environmental Contamination and Toxicology, v. 15, no. 5, p. 513-517.

Besser, J.M., Huckins, J.N., Little, E.E., and La Point, T.W., 1989, Distribution and bioaccumulation of selenium in aquatic microcosms: Environmental Pollution, v. 62 , no. 1, p. $1-12$.

Besser, J.M., Canfield, T.J., and La Point, T.W., 1993, Bioaccumulation of organic and inorganic selenium in a laboratory food chain: Environmental Toxicology and Chemistry, v. 12, no. 1, p. 57-72.

Bertram, P.E., and Brooks, A.S., 1986, Kinetics of accumulation of selenium from food and water by fathead minnows: Water Research, v. 20, no. 7, p. 877-884.

Birkner, J.H., 1978, Selenium in aquatic organisms from seleniferous habitats: Fort Collins, Colorado State University, Ph.D. dissertation, 121 pages.

California County of Orange, 2004, Newport Bay shellfish harvesting assessment: prepared by Eisenberg, Olivieri and Associates and Kinnetic Laboratories Incorporated for County of Orange Resources and Development Management Department, Anaheim, California, $121 \mathrm{p}$.

California County of Orange, 2006, Submittal of decision package on appropriateness to commence development of a site-specific objective for selenium in the Newport Bay Watershed for the compliance with provision D.15.i(13) of order no, R82004-0021: Anaheim, California, County of Orange Resources and Development Management Department, 3 p.

California Nitrogen and Selenium Management Program, 2006a, Rationale for a selenium site-specific objective, Newport Bay Watershed: prepared by Larry Walker Associates, Davis, California and CH2M Hill, Sacramento, California, for California Santa Ana Regional Water Quality Control Board, Riverside California, 33 p. and attachment I [http://www.ocnsmp.com, last accessed June 3, 2009]. 
California Nitrogen and Selenium Management Program, 2006b, Sources and loads and identification of data gaps for selenium in the Newport Bay Watershed (Interim Report): prepared by CH2M Hill, Sacramento, California, for California Santa Ana Regional Water Quality Control Board, Riverside California, 103 p.

California Nitrogen and Selenium Management Program, 2009 (in press), Sources and loads for selenium in the Newport Bay Watershed (Final Report): prepared by CH2M Hill, Sacramento, California for California Santa Ana Regional Water Quality Control Board, Riverside California.

California Santa Ana Regional Water Quality Control Board, 2004, General wastedischarge requirements for short-term groundwater-related discharges and de minimus wastewater discharges to surface waters within the San Diego Creek/Newport Bay watershed: Riverside, California, California Santa Ana Regional Water Quality Control Board, Order no. R8-2004-0021, NPDES No. CAG998002, 30 p.

Casey, R., 2005, Results of aquatic studies in the McLeod and Upper Smoky River Systems: Edmonton, Alberta, Alberta Environment, 72 p.

[http://environment.gov.ab.ca/info/library/7743.pdf, last accessed June 3, 2009].

Cavitt, J.F., 2007, Concentration and effects of selenium on breeding shorebirds at Great Salt Lake, in Development of a selenium standard for the open waters of the Great Salt Lake, Project 1A, Utah Department of Environmental Quality, Division of Water Quality, Salt Lake City, Utah, 49 p.

[http://www.deq.utah.gov/Issues/GSL_WQSC/docs/051608_Appendix_C.pdf, last accessed June 3, 2009].

CH2M Hill, 2008a, Datasets for San Diego Creek watershed and Newport Bay: EXCEL Spreadsheets, C. Arenal, CH2M Hill, Sacramento, California.

CH2M Hill, 2008b, Trophic transfer factors from diet to bird eggs: Technical Memo, H.M. Ohlendorf, CH2M Hill, Sacramento, California, 9 p.

Cleveland, L., Little, E.E., Buckler, D.R., and Wiedmeyer, R.H., 1993, Toxicity and bioaccumulation of waterborne and dietary selenium in juvenile bluegill (Lepomis macrochirus): Aquatic Toxicology, v. 27, no. 3-4, p. 265-280.

Cutter, G.A., and Bruland, K.W., 1984, The marine biogeochemistry of selenium-a reevaluation: Limnology and Oceanography, v. 29, p. 1179-1192.

DeForest, D.K., Brix, K.V., and Adams, W.J., 2007, Assessing metal bioaccumulation in aquatic environments - the inverse relationship between bioaccumulation factors, trophic transfer factors, and exposure concentration: Aquatic Toxicology, v. 84, p. 236-246.

Fisher, N.S., and Reinfelder, J.R., 1991, Assimilation of selenium in the marine copepod Acartia tonsa studied with a radiotracer ratio method: Marine Ecology Progress Series, v. 70, no. 2, p. 157-164.

Fowler, S.W., and Benayoun, G., 1976a, Influence of environmental factors on selenium flux in two marine invertebrates: Marine Biology, v. 37, no. 1, p. 59-68.

Fowler, S.W., and Benayoun, G., 1976b, Selenium kinetics in marine zooplankton: Marine Science Communications, v. 2, no. 1, p. 43-67.

Graham, R.V., Blaylock, B.G., Hoffman, F.O., and Frank, M.L., 1992, Comparison of selenomethionine and selenite cycling in freshwater experimental ponds: Water, Air, and Soil Pollution, v. 62, no. 1-2, p. 25-42. 
Greater Yellowstone Coalition, 2005 and 2006, Technical reports on selenium concentrations in water, macrophytes, macroinvertebrates, and fish: Bozeman, Montana, Greater Yellowstone Coalition [http://greateryellowstone.org/media/pdf/Se-sampling-data/seleniumoverview.pdf, last accessed June 3, 2009].

Hamilton, S.J., and Buhl, K.J., 2004, Selenium in water, sediment, plants, invertebrates, and fish in the Blackfoot River drainage: Water, Air, and Soil Pollution, v. 159, no. 1-4, p. 3-34.

Hamilton, S.J., and Buhl, K.J., 2005, Selenium in the Blackfoot, Salt, and Bear River watersheds: Environmental Monitoring and Assessment, v. 104, no. 1-3, p. 309339.

Hamilton, S.J., Buhl, K.J., and Lamothe, P.J., 2004, Selenium and other trace elements in water, sediment, aquatic plants, aquatic invertebrates, and fish from streams in SE Idaho near phosphate mining, in Hein, J.R., ed., Life cycle of the Phosphoria Formation - from deposition to post-mining environment: New York, Elsevier, p. 483-525.

Harding, L.E., Graham, M., and Paton, D., 2005, Accumulation of selenium and lack of severe effects on productivity of American dippers (Cinclus Mexicanus) and spotted sandpipers (Actitis Macularia): Archives of Environmental Contamination and Toxicology, v. 48, no. 3, p. 414-423.

Hibbs, B.J., and Lee, M.M., 2000, Sources of selenium in the San Diego Creek watershed, Orange County, California: Department of Geological Sciences, California State University, Los Angeles andDefend the Bay, Newport Beach, California, $123 \mathrm{p}$.

Ke, C., and Wang, W.-X., 2001, Bioaccumulation of Cd, Se, and Zn in an estuarine oyster (Crassostrea rivularis) and a coastal oyster (Saccostrea glomerata): Aquatic Toxicology, v. 56, no. 1, p. 33-51.

Kiffney, P.K., and Knight, A.W., 1990, The toxicity and bioaccumulation of selenate, selenite, and seleno-L-methionine in the cyanobacterium Anabaena flos-aquae: Archives of Environmental Contamination and Toxicology, v. 19, no. 4, p. 488494.

Larry Walker Associates, Inc. and CH2M Hill, 2007, Selenium site-specific objectiveprocedural and technical elements:, Larry Walker Associates, Davis California and CH2M Hill, Sacramento, California, Technical Memorandum, 37 p.

Lee, B.-G., Lee, J.-S., and Luoma, S.N., 2006, Comparison of selenium bioaccumulation in the clams Corbicula fluminea and Potamocorbula amurensis - a bioenergetic modeling approach: Environmental Toxicology and Chemistry, v. 25, no. 7, p. 1933-1940.

Lemly, A.D., 1993, Metabolic stress during winter increases the toxicity of selenium to fish: Aquatic Toxicology, v. 27, no. 1-2, p. 133-158.

Luoma, S.N., and Rainbow, P.S., 2005, Why is metal bioaccumulation so variable? Biodynamics as a unifying concept: Environmental Science and Technology, v. 39, no. 7, p. 1925-1931. 
Luoma, S.N., Johns, C., Fisher, N.S., Steinberg, N.A., Oremland, R.S., and Reinfelder, J.R., 1992, Determination of selenium bioavailability to a benthic bivalve from particulate and solute pathways: Environmental Science and Technology, v. 26, no. 3, p. 485-491.

Marden, B.T., 2008, Synoptic survey of the pelagic zone - selenium in water, seston, and Artemia, in Development of a selenium standard for the open waters of the Great Salt Lake, Project 2B, Utah Department of Environmental Quality, Division of Water Quality, Salt Lake City, Utah, 153 p. [http://www.deq.utah.gov/Issues/GSL_WQSC/docs/ 111708 Full_\%20Report_Final_DWQ_version_2008.pdf, last accessed June 3, 2009].

McDonald, L.E. and Strosher, M.M., 1998, Selenium mobilization from surface coal mining in the Elk River Basin, British Columbia - a survey of water, sediment, and biota: Pollution Prevention, Ministry of Environment, Lands and Parks, Kootenay Region, Cranbrook, British Columbia, 66 p. [http://www.env.gov.bc.ca/eirs/epd/, last accessed June 3, 2009].

McGeer, J.C., Brix, K.V., Skeaff. J.M., DeForest, D.K., Brigham, S.I., Adams, W.J., and Green, A., 2003, Inverse relationship between bioconcentration factor and exposure concentration for metals - implications for hazard assessment of metals in the aquatic environment: Environmental Toxicology and Chemistry, v. 22, no.5, p. 1017-1037.

Meixner, T., Hibbs, B.J., Sjolin, J., and Walker, J., 2004, Sources of selenium, arsenic, and nutrients in the Newport Bay Watershed: State Water Resources Control Board, California, Department of Geological Sciences, California State University, Los Angeles, Agreement no. 00-200-180-01, Final Report, 145 p.

Ni, I.-H., Chan, S.M., and Wang, W.-X., 2005, Influences of salinity on the biokinetics of $\mathrm{Cd}$, Se, and $\mathrm{Zn}$ in the intertidal mudskipper Periophthalmus cantonensis: Chemosphere, v. 61, no. 11, p. 1607-1617.

Ohlendorf, H.M., 2003, Ecotoxicology of selenium, in Hoffman, D.J., Rattner, B.A., Burton, Jr., G.A., Cairns, Jr., J., eds., Handbook of Ecotoxicology ( $2^{\text {nd }}$ ed.): Boca Raton, Lewis Publishers, p. 465-500.

Okazaki, R.K., and Panietz, M.H., 1981, Depuration of twelve trace metals in tissues of the oysters Crassostrea gigas and C. virginica: Marine Biology, v. 63, p 113.

Piper, D.Z., and Isaacs, C.M., 1994, Geochemistry of minor elements in the Monterey Formation, California; seawater chemistry of deposition: U.S. Geological Survey Professional Paper 1566, $41 \mathrm{p}$.

Presser, T.S., and Luoma, S.N., 2006, Forecasting selenium discharges to the San Francisco Bay-Delta Estuary - ecological effects of a proposed San Luis Drain extension: U.S. Geological Survey Professional Paper 1646, 196 p.

Rainbow, P.S., and Wang, W.-X., 2001, Comparative assimilation of Cd, Cr, Se and Zn by the barnacle Elminius modestus from phytoplankton and zooplankton diets: Marine Ecology Progress Series, v. 218, p. 239-248.

Reinfelder, J.R., Wang, W.-X., Luoma, S.N., and Fisher, N.S., 1997, Assimilation efficiencies and turnover rates of trace elements in marine bivalves - a comparison of oysters, clams and mussels: Marine Biology, v. 129, no. 3, p. 443452. 
Reinfelder, J.R., Fisher, N.S., Luoma, S.N., Nichols, J.W., and Wang, W-X., 1998, Trace element trophic transfer in aquatic organisms; a critique of the kinetic model approach: The Science of the Total Environment, v. 219, no. 2-3, p. 117-135.

Roditi, H.A., and Fisher, N.S., 1999, Rates and routes of trace elements uptake in zebra mussels: Limnology and Oceanography, v. 44, no. 7, p. 1730-1749.

Saiki, M.K., Jennings, M.R., and Brumbaugh, W.G., 1993, Boron, molybdenum, and selenium in aquatic food chains from the lower San Joaquin River and its tributaries, California: Archives of Environmental Contamination and Toxicology, v. 24, no. 3, p. 307-319.

Saiki, M.K., Martin, B.A., and May, T.W., 2008, Year 3 summary report-baseline selenium monitoring of agricultural drains operated by the Imperial Irrigation District in the Salton Sea Basin: U.S. Geological Survey Open-File Report 2008$1271,75 \mathrm{p}$.

Schlekat, C.E., Lee, B.-G., and Luoma, S.N., 2002, Assimilation of selenium from phytoplankton by three benthic invertebrates - effect of phytoplankton species: Marine Ecology Progress Series, v. 237, p. 79-85.

Schlekat, C.E., Purkerson, D.G., and Luoma, S.N., 2004, Modeling selenium bioaccumulation through arthropod food webs in San Francisco Bay, California, USA: Environmental Toxicology and Chemistry, v. 23, no. 12, p. 3003-3010.

Sutula, M., Bay, S., Santolo, G., and Zembal, 2005, Organochlorine, trace elements, and metal contaminants in the food web of the lightfooted clapper rail, Upper Newport Bay, California: Technical Report 467, Southern California Coastal Water Research Project, Westminster, California, 42 p.

U.S. Environmental Protection Agency, 2002, Total Maximum Daily Loads for Toxic Pollutants San Diego Creek and Newport Bay, California, U.S. Environmental Protection Agency, Region 9, 88 p. [http://www.ocwatersheds.com/Watersheds/default.aspx?ID=10000300, last accessed June 3, 2009].

Wang, W.-X , 2002, Interactions of trace metals and different marine food chains: Marine Ecology Progress Series, v. 243, p. 295-309.

Wang, W.-X., and Fisher, N.S., 1998, Accumulation of trace elements in a marine copepod: Limnology and Oceanography, v. 43, no. 2, p. 273-283.

Wang, W.-X., Reinfelder, J.R., Lee, B-G, and Fisher, N.S, 1996a, Assimilation and regeneration of trace elements by marine copepods: Limnology and Oceanography, v. 41, no. 2, p. 70-81.

Wang, W.-X., Fisher, N.S., and Luoma, S.N., 1996b, Kinetic determinations of trace element bioaccumulation in the mussel Mytilus edulis: Marine Ecology Progress Series, v. 140, no. 1-3, p. 91-113.

Wang, W.-X., Qiu, J.-W., and Qian, P.-Y., 1999, The trophic transfer of Cd, Cr, and Se in the barnacle Balanus Amphitrite from planktonic food: Marine Ecology Progress Series. v. 187, p. 191-201. 
Wurtsbaugh, W., 2007, Preliminary analyses of selenium bioaccumulation in benthic food webs of the Great Salt Lake, Utah, in, Development of a selenium standard for the open waters of the Great Salt Lake, Utah Department of Environmental Quality, Division of Water Quality, Salt Lake City, Utah, 51 p. [http://www.deq.utah.gov/ISsues/GSL_WQSC/docs/051408_Appendix_E.pdf, last accessed June 3, 2009].

$\mathrm{Xu}, \mathrm{Y}$., and Wang, W.-X., 2002, Exposure and potential food chain transfer factor of Cd, $\mathrm{Se}$, and $\mathrm{Zn}$ in marine fish Lutjanus argentimaculatus: Marine Ecology Progress Series, v. 238, p. 173-186.

Zhang, G.H., Hu, M.H., and Huang, Y.P., 1990, Se uptake and accumulation in marine phytoplankton and transfer of Se to the clam Puditapes philippnarum: Marine Environmental Research, v. 30, no. 3, p. 179-190.Tables 
Tables

Table 1. Total water-column Se concentrations and Se speciation for the San Diego Creek watershed.

\begin{tabular}{|c|c|c|c|c|c|c|}
\hline location & season & $\begin{array}{c}\text { 75th percentile } \\
(\mu \mathrm{g} / \mathrm{L})\end{array}$ & $\begin{array}{l}\text { mean } \\
(\mu \mathrm{g} / \mathrm{L})\end{array}$ & $\begin{array}{c}\text { minimum } \\
(\mu \mathrm{g} / \mathrm{L})\end{array}$ & $\begin{array}{c}\text { maximum } \\
(\mu \mathrm{g} / \mathrm{L})\end{array}$ & $\begin{array}{c}\text { selenite }(\%) \\
\text { (selenite/dissolved Se) }\end{array}$ \\
\hline Upper PCW & dry & 2.5 & 5.0 & 0.1 & 24.7 & up to $21 \%$ \\
\hline Upper SDC & dry & 4.6 & 2.9 & 0.7 & 6.1 & up to $21 \%$ \\
\hline Lower PCW & dry & 31.0 & 21.8 & 1.6 & 44.0 & up to $22 \%$ \\
\hline Lower SDC & dry & 16.0 & 12.3 & 1.2 & 37.5 & up to $25 \%$ \\
\hline IRWD wetlands & dry & 15.6 & 11.7 & 4.0 & 16.9 & up to $39 \%$ \\
\hline UCl wetlands & dry & 2.9 & 2.3 & 1.3 & 3.0 & up to $100 \%$ \\
\hline \multicolumn{7}{|c|}{ OTHER } \\
\hline Marsh Drains & dry & 24.2 & 14.9 & 0.1 & 162.0 & \\
\hline Non-Marsh Drains & dry & 4.7 & 5.4 & 0.5 & 79.8 & \\
\hline SADC & dry & 14.0 & 9.9 & 2.2 & 19.0 & up to $11 \%$ \\
\hline IRWD (IN)a & dry & 19.1 & 12.9 & 4.0 & 20.7 & \\
\hline IRWD (OUT)a & dry & 13.3 & 10.5 & 4.0 & 14.1 & \\
\hline
\end{tabular}

${ }^{\mathrm{a}}$ denotes location near inflow or outflow. 
Table 2a. Dissolved or total water-column Se concentrations; Se concentrations in bed sediment and algae; and calculated Kds for the San Diego Creek watershed (freshwater sites). [Kds are calculated from matched (that is, temporally and spatially paired) and 75th percentile datasets when data are available. The average of the sediment and algae Se concentrations are preferentially used, if available, to calculate $\mathrm{Kd}$. Additional available data are listed in brackets ([ ]) to substantiate data ranges for sites. See additional notes in text on assemblage of table. $d w=$ dry weight; $n=$ number of samples.]

\begin{tabular}{|c|c|c|c|c|c|}
\hline location, season, and speciation & water $(\mu \mathrm{g} / \mathrm{L})$ & $\begin{array}{l}\text { bed sediment } \\
(\mu \mathrm{g} / \mathrm{g} \mathrm{dw})\end{array}$ & $\begin{array}{c}\text { algae } \\
(\mu g / g d w)\end{array}$ & $\begin{array}{c}\text { average } \\
\text { (sediment and } \\
\text { algae) }(\mu g / g d w)\end{array}$ & $\begin{array}{c}\mathrm{K}_{\mathrm{d}} \\
\text { sediment/water } \\
(\mu \mathrm{g} / \mathrm{kg} / \mu \mathrm{g} / \mathrm{L}) \\
\end{array}$ \\
\hline Upper SDC (matched) DRY & 0.79 & 0.2 & & & 253 \\
\hline Upper SDC (75th percentile) DRY & 4.6 & $0.2(n=1)$ & & & 43 \\
\hline $\begin{array}{l}\text { Upper PCW (matched) DRY } \\
\text { (up to } 21 \% \text { selenite) }\end{array}$ & $\begin{array}{c}3.4 \text { total } \\
3.2 \text { dissolved }\end{array}$ & $\begin{array}{l}0.6 \\
0.6 \\
\end{array}$ & $\begin{array}{l}1.2 \\
1.2 \\
\end{array}$ & $\begin{array}{l}0.9 \\
0.9 \\
\end{array}$ & $\begin{array}{l}264 \\
281 \\
\end{array}$ \\
\hline Upper PCW (75th percentile) DRY & 2.5 & $0.6(n=1)$ & & & 240 \\
\hline Non-marsh drains (matched) & none & none & & & none \\
\hline Non-marsh drains (75th percentile) & $\begin{array}{l}\text { 4.7 DRY } \\
\text { 3.65 WET }\end{array}$ & none & & & none \\
\hline Marsh drain (matched) DRY & $\begin{array}{c}0.25-28.1 \\
11.1 \\
\end{array}$ & none & $\begin{array}{l}0.6 \\
2.4 \\
3.1 \\
3.8 \\
3.1 \\
\end{array}$ & & 279 \\
\hline Marsh Drains (75th percentile) & $\begin{array}{l}\text { 24.2 DRY } \\
\text { 17 WET }\end{array}$ & none & & & none \\
\hline $\begin{array}{l}\text { Lower PCW (matched) DRY } \\
\text { (up to } 22 \% \text { selenite) }\end{array}$ & 8.1 & {$[0.86]$} & $\begin{array}{c}3.6 \\
{[2.5,1.6]} \\
\end{array}$ & & $\begin{array}{c}444 \\
\text { based on algae } \\
\end{array}$ \\
\hline Lower PCW (matched) WET & 30 & & 6.7 & & 223 \\
\hline Lower PCW (75th percentile) & $31 \mathrm{ALL}$ & $\begin{array}{c}4.1 \mathrm{n}=6 \mathrm{ALL} \\
(0.7-13.8)\end{array}$ & & & 132 \\
\hline $\begin{array}{l}\text { Lower SDC (matched) } \\
\text { (up to } 25 \% \text { selenite) }\end{array}$ & $\begin{array}{c}\text { 3.3 DRY }(n=1) \\
\text { 29 DRY }(n=1) \\
\text { 4.1 DRY (May) } \\
19.2 \\
\text { 25.3 WET }(n=1) \\
\text { 18.4 WET }(n=1)\end{array}$ & $\begin{array}{c}0.2(n=1) \text { DRY } \\
0.54(n=2) \text { DRY } \\
0.66 \text { (range } 0.5-1.6)^{a} \\
2.6 \text { (range 0.17-2.6) WET } \\
2.6 \text { (range } 0.17-2.6) \text { WET } \\
{[3.1]}\end{array}$ & $\begin{array}{c}0.64(n=1) \\
\text { DRY }\end{array}$ & & $\begin{array}{c}61 \\
19 \\
156 \\
34 \\
103 \\
141\end{array}$ \\
\hline $\begin{array}{l}\text { Lower SDC 75th percentile } \\
\text { mean }\end{array}$ & $\begin{array}{c}17 \mathrm{DRY} \\
12.7\end{array}$ & $\begin{array}{l}1.16 \\
0.95\end{array}$ & & & $\begin{array}{l}68 \\
75\end{array}$ \\
\hline
\end{tabular}




\begin{tabular}{|c|c|c|c|c|c|}
\hline $\begin{array}{l}\text { minimum } \\
\text { maximum }\end{array}$ & $\begin{array}{c}1.2 \\
37.5\end{array}$ & $\begin{array}{l}0.09 \\
6.2\end{array}$ & & & $\begin{array}{c}75 \\
166\end{array}$ \\
\hline $\begin{array}{l}\text { Lower SDC, 75th percentile } \\
\text { mean } \\
\text { minimum } \\
\text { maximum }\end{array}$ & $\begin{array}{l}19.7 \text { WET } \\
13.3 \\
0.75 \\
39\end{array}$ & $\begin{array}{c}1.16 \\
0.95 \\
0.09 \\
6.2\end{array}$ & & & $\begin{array}{c}59 \\
71 \\
120 \\
159\end{array}$ \\
\hline $\begin{array}{l}\text { IRWD wetlands (matched) WET } \\
\text { pond } 1 \\
\text { pond } 1 \text { anti-predator trench } \\
\text { pond } 3 \\
\text { pond } 3 \text { anti-predator trench } \\
\text { stream and riparian zone } \\
\text { (up to } 39 \% \text { selenite) }\end{array}$ & $\begin{array}{c}21.1 \\
21.1 \\
20.4 \\
20.4 \\
\text { (assume 21) }\end{array}$ & $\begin{array}{l}2.3 \\
2.7 \\
4.5 \\
5.8 \\
6.9\end{array}$ & $5.7 ; 9.3$ & 7.3 & $\begin{array}{l}109 \\
128 \\
221 \\
284 \\
348\end{array}$ \\
\hline IRWD wetlands (75thpercentle) ALL & 16.0 & 3.72 & & & 232 \\
\hline $\begin{array}{l}\text { IRWD wetlands IN } \\
\text { ( } 75 \text { th percentile) ALL } \\
\text { (up to } 9 \% \text { selenite) }\end{array}$ & 21.5 in & & & & \\
\hline $\begin{array}{l}\text { IRWD wetlands OUT } \\
\text { ( } 75 \text { th percentile) ALL } \\
\text { (up to } 39 \% \text { selenite) }\end{array}$ & 12.3 out & & & & \\
\hline $\begin{array}{l}\text { UCI wetlands (matched) } \\
\text { (up to } 100 \% \text { selenite) }\end{array}$ & none & & & & none \\
\hline $\begin{array}{l}\text { UCl wetlands (DRY) 75th percentile } \\
\text { mean } \\
\text { minimum } \\
\text { maximum }\end{array}$ & $\begin{array}{l}2.77(n=2) \\
2.04 \\
1.31 \\
2.77\end{array}$ & $\begin{array}{c}2.18(n=5) \\
1.6 \\
0.86 \\
2.6\end{array}$ & & & $\begin{array}{l}787 \\
784 \\
656 \\
939\end{array}$ \\
\hline $\begin{array}{l}\text { Delhi Channel (SADC) DRY } \\
\text { (up to } 11 \% \text { selenite) }\end{array}$ & & 0.49 & 2.0 & & none \\
\hline Delhi Channel (75th percentile) & 15 & 1.23 (range 0.5-4.0) & & & 82 \\
\hline
\end{tabular}

Delhi Channel (75th percentile)

a sand to silty-sand sample.

Table 2b. Statistics for calculated $\mathrm{K}_{\mathrm{d}} \mathrm{s}$ based on table 2a data.

\begin{tabular}{|l|c|c|c|c|c|}
\hline $\mathrm{K}_{d}$ & all sites & all sites except UCI wetlands & UCI wetlands & IRWD wetlands & UCI and IRWD wetlands \\
\hline mean & 241 & 168 & 792 & 220 & 449 \\
\hline median & 159 & 136 & 786 & 226 & 271 \\
\hline 75th percentile & 279 & 238 & 825 & 348 & 752 \\
\hline Maximum & 939 & 444 & 939 & 109 & 939 \\
\hline Minimum & 19 & 19 & 656 & 6 & 109 \\
\hline $\mathrm{n}$ (number of data points) & 33 & 29 & 4 & 10 \\
\hline
\end{tabular}


Table 3. Dissolved water-column Se concentrations and speciation for the Newport Bay estuary.

\begin{tabular}{|l|c|c|}
\hline location & dissolved or range of dissolved $(\mu \mathrm{g} / \mathrm{L})$ & selenite or range of selenite $(\%)$ \\
\hline mouth of estuary at $0 \mathrm{ppt}$ & 24 extrapolated (see figure 5) & 11 \\
\hline Upper Bay at 15 ppt & 14.4 & 19 \\
\hline Upper Bay at 27 ppt & 3.5 & $18-32$ \\
\hline Upper Bay at 28 ppt & $2.4-1.8$ & $14-25$ \\
\hline Upper Bay at 30 ppt & $1.3-1.0$ & $21-48$ \\
\hline Upper/Lower Bay at 33 ppt & $0.97-0.29$ & \\
\hline Lower Bay & $0.15-0.11$ & \\
\hline Lower Bay & $0.08-0.06$ & \\
\hline
\end{tabular}

Table 4. Water-column and suspended particulate Se concentrations in Upper Newport Bay in a transect from the near the mouth of San Diego Creek into the upper bay to salinities of $33.1 \mathrm{ppt}$. [Calculated $\mathrm{K}_{d} \mathrm{~S}$ and percentages of dissolved selenite also are shown. ppt = parts per thousand; $\mathrm{dw}=$ dry weight]

\begin{tabular}{|c|c|c|c|c|c|}
\hline $\begin{array}{c}\text { salinty } \\
(\mathrm{ppt})\end{array}$ & $\begin{array}{c}\text { dissolved } \\
(\mu \mathrm{g} / \mathrm{L})\end{array}$ & $\begin{array}{c}\text { total } \\
(\mu \mathrm{g} / \mathrm{L})\end{array}$ & $\begin{array}{c}\text { particulate } \\
(\mu \mathrm{gg} / \mathrm{g} \mathrm{dw})\end{array}$ & $\begin{array}{c}\text { \% selenite } \\
\text { (selenite/dissolved) }\end{array}$ \\
\hline 15.1 & 14.4 & 18.4 & 1.54 & 107 & 10.7 \\
\hline 26.6 & 3.50 & 4.02 & 0.39 & 111 & 18.6 \\
\hline 30.2 & 1.79 & 2.26 & 0.18 & 101 & 20.1 \\
\hline 28.0 & 2.32 & 2.47 & 0.27 & 116 & 22.0 \\
\hline 31.4 & 1.13 & 1.60 & 0.24 & 212 & 31.9 \\
\hline 28.7 & 2.42 & 2.97 & 0.21 & 87 & 17.8 \\
\hline 31.6 & 1.27 & 1.43 & 0.17 & 134 & 13.7 \\
\hline 30.5 & 1.31 & 1.67 & 0.24 & 183 & 18.9 \\
\hline 31.0 & 1.32 & 1.72 & 0.25 & 144 & 25.4 \\
\hline 30.8 & 1.18 & 1.53 & 0.17 & 212 & 27.2 \\
\hline 31.4 & 0.991 & 1.37 & 0.21 & 287 & 14.1 \\
\hline 31.6 & 0.837 & 1.02 & 0.24 & 382 & 31.5 \\
\hline 32.0 & 0.967 & 0.985 & 0.17 & 353 & 29.0 \\
\hline 32.8 & 0.445 & 0.548 & 0.17 & 776 & 32.0 \\
\hline 33.0 & 0.482 & 0.624 & 0.17 & 297 & 20.8 \\
\hline 32.8 & 0.438 & 0.744 & 0.34 & 335 & 27.6 \\
\hline 32.2 & 0.674 & 0.839 & 0.20 & 366 & 30.1 \\
\hline 32.8 & 0.508 & 0.698 & 0.17 & 578 & 47.6 \\
\hline 32.9 & 0.465 & 0.506 & 0.17 & 408 & 33.6 \\
\hline 33.0 & 0.294 & 0.351 & 0.17 & 264 mean & \\
\hline 33.1 & 0.417 & 0.466 & 0.17 & 35375 th percentile & \\
\hline & & & & & \\
\hline & & & & & \\
\hline
\end{tabular}

Table 5. Water-column and sediment Se concentrations and calculated $K_{d} s$ in a gradient from landward to seaward in Newport Bay. [dw = dry weight]

\begin{tabular}{|l|c|c|c|}
\hline location (with increasing residence time) & sediment $(\mu \mathrm{g} / \mathrm{g} \mathrm{dw})$ & dissolved $(\mu \mathrm{g} / \mathrm{L})$ & $\mathrm{K}_{d}$ \\
\hline Newport Dunes & 1.07 & 0.15 & 6,933 \\
\hline Bayside DeAnza & 1.05 & 0.11 & 9,679 \\
\hline Bahia Corinthian & 1.17 & 0.07 & 16,675 \\
\hline Balboa Yacht Basin & 1.06 & 0.06 & 17,026 \\
\hline H\&J Moorings & 1.10 & 0.08 & 13,508 \\
\hline Lido Village & 1.32 & 0.06 & 20,000 \\
\hline Lido Anchorage & 1.57 & 0.07 & 25,000 \\
\hline Harbor Towers & 2.98 & 0.07 & 42,715 \\
\hline
\end{tabular}


Table 6. Experimental data for invertebrate physiological factors and calculated kinetic TTFs for invertebrates.

\begin{tabular}{|c|c|c|c|c|c|}
\hline \multicolumn{6}{|c|}{ Marine Environments } \\
\hline species & $\mathrm{AE}$ & IR & ke & TTF (AE X IR/ke) & Reference \\
\hline copepod (Acartis tonsa) & 0.97 & $0.42^{a}$ & $0.13^{b}$ & 3.1 & Fisher and Reinfelder, 1991 \\
\hline copepod (Temora longicornis) & 0.55 & 0.42 & 0.155 & 1.5 & Wang and Fisher, 1998 \\
\hline copepod (A. tonsa; T. longicornis) & 0.8 & $0.42^{a}$ & 0.19 & 1.8 & Wang and othersl., 1996a \\
\hline $\begin{array}{l}\text { copepod (Oithona; Limnoithona; Tortanus; Acartia; } T \text {. } \\
\text { longicornis) }\end{array}$ & 0.50 & 0.42 & 0.155 & 1.35 & Schlekat and others, 2004 \\
\hline mysid (Neomysis mercedis) & $0.61-0.73$ & 0.45 & 0.25 & $1.1-1.3$ & Schlekat and others, 2004 \\
\hline amphipod (Leptocheirus plumulosus) & 0.45 & 0.20 & 0.15 & 0.6 & Schlekat and others, 2004 \\
\hline clam (Corbula amurensis) & $0.45-0.80$ & 0.25 & 0.025 & $4.5-8.0$ & Schlekat and others, 2002 \\
\hline clam (C. amurensis) & $0.36-0.54$ & 0.25 & 0.025 & $3.6-5.4$ & Lee and others, 2006 \\
\hline clam (Corbicula fluminea) & $0.29-0.81$ & 0.05 & 0.010 & $1.45-4.05$ & Lee and others, 2006 \\
\hline clam (Macoma balthica) & $0.22-0.86$ & 0.25 & $0.012^{c}$ & 11.2 (using mean $A E$ ) & Luoma and others, 1992 \\
\hline clam (M. balthica) & 0.54 (mean) & 0.25 & $0.030^{d}$ & 4.5 & Luoma and others, 1992 \\
\hline clam (Ruditapes philippnarum) & $0.52-0.70$ & $0.25^{a}$ & $0.013^{e}$ & $10-13.5$ & Zhang and others, 1990 \\
\hline clam (Mercenaria mercenaria) & 0.92 & $0.25^{a}$ & $0.010^{f}$ & 23 & Reinfelder and others, 1997 \\
\hline oyster (Crassostrea virginica) & $0.45-0.70$ & $0.25^{a}$ & $0.069 \mathrm{~g}$ & $1.6-2.5$ & Reinfelder and others, 1997 \\
\hline oyster (Crassostrea rivularis) & 0.55 & 0.45 & & & Ke and Wang, 2001 \\
\hline oyster (Saccostrea glomerata) & 0.45 & 0.32 & & & Ke and Wang, 2001 \\
\hline mussel (Mytilus edulis) & 0.31 & 0.27 & 0.022 & 3.8 & Wang and others, 1996b \\
\hline mussel (M. edulis) & 0.72 & 0.27 & 0.022 & 8.8 & Reinfelder and others, 1997 \\
\hline barnacle (Balanus amphitrite) & $0.63-0.79$ & 0.40 & 0.014 & $18-22.6$ & Wang and others, 1999 \\
\hline barnacle (Elminus modestus) & $0.34-0.74$ & 0.40 & 0.0137 & $9.9-21.6$ & Rainbow and Wang, 2001 \\
\hline \multicolumn{6}{|c|}{ Freshwater Environments } \\
\hline Species & $\mathrm{AE}$ & IR & ke & TTF (AE X IR/ke) & Reference \\
\hline zebra mussel (Dreissena polymorpha) & $0.28-0.46$ & 0.42 & 0.026 & $4.5-7.4$ & Roditi and Fisher, 1999 \\
\hline clam (Corbicula fluminea) & $0.29-0.81$ & 0.05 & 0.010 & $1.45-4.05$ & Lee and others, 2006 \\
\hline
\end{tabular}

a assumed IR

${ }^{b}$ calculated from 5.25 day half-life

c chosen from Fowler and Benayoun, 1976a; Zhang and others, 1990; and Okazaki and Panietz, 1981

${ }^{d}$ calculated from 23 day half-life [efflux $(/ d)=0.69 /$ half-life $(d)$ ], Reinfelder and others, 1997

e calculated from 52 day half-life

${ }^{f}$ calculated from 70 day half-life

g calculated from 10 day half-life 
Table 7. Field-derived TTFs for invertebrates from field datasets (temporally and spatially matched data-pairs), with experimentally derived TTFs given for comparison

\begin{tabular}{|c|c|c|c|}
\hline invertebrate & kinetic TTF & field TTF & reference \\
\hline \multicolumn{4}{|c|}{ Freshwater } \\
\hline amphipod & & 0.94 & Birkner, 1978; Saiki and others, 1993 \\
\hline zooplankton & & 1.5 & Saiki and others, 1993 \\
\hline mayfly & & 2.7 & Casey, 2005 \\
\hline caddisfly & & 3.2 & Casey, 2005 \\
\hline cranefly & & 2.3 & Casey, 2005 \\
\hline stonefly & & 2.6 & Casey, 2005 \\
\hline all flies composite & & 3.2 & Harding and others, 2005 \\
\hline damselfly & & 2.6 & Birkner, 1978 \\
\hline midge (chironomid) & & 2.7 & Birkner, 1978; Saiki and others, 1993 \\
\hline corixid (waterboatman) & & 2.14 & Birkner, 1978 \\
\hline crayfish & & 1.5 & Birkner, 1978; Saiki and others, 1993 \\
\hline daphnia & & 1.9 & Besser and others, 1989 \\
\hline zebra mussel (D. polymorpha) & $4.5-7.4$ & & Roditi and Fisher 1999 \\
\hline clam (C. fluminea) & $1.5-4.1$ & & Lee et al 2006 \\
\hline \multicolumn{4}{|c|}{ Marine/Estuarine } \\
\hline amphipod & 0.6 & & Schlekat and others, 2004; \\
\hline copepod & 1.35 & & Schlekat and others, 2004 \\
\hline euphausiid & & 1.3 & Fowler and Benayoun 1976b \\
\hline mysid & 1.3 & & Schlekat and others, 2004; \\
\hline brine shrimp adult & & 4.2 & Marden, 2008 \\
\hline brine shrimp nauplius & & 2.6 & Marden, 2008 \\
\hline brine shrimp cysts & & 2.2 & Marden, 2008 \\
\hline brine fly adult & & 1.8 & Cavitt, 2007; Wurtzbach, 2007 \\
\hline brine fly larvae & & 1.5 & Cavitt, 2007; Wurtzbach, 2007 \\
\hline
\end{tabular}


Table 8. Invertebrate Se concentrations for the San Diego Creek watershed. [Means and ranges or values (if only two values are available) are shown. dw = dry weight; $n=$ number of samples.]

\begin{tabular}{|c|c|c|c|c|c|c|}
\hline species & Upper SDC and PCW & Marsh Drains & Lower SDC (DRY) & Lower PCW & IRWD wetlands & $\mathrm{UCl}$ wetlands \\
\hline \multicolumn{7}{|c|}{ invertebrate $(\mu \mathrm{g} / \mathrm{g} \mathrm{dw})$} \\
\hline zooplankton & & & & & $6.8(n=1)$ & \\
\hline amhipod & & & & $8.7(n=1)$ & & \\
\hline midge larvae (chironomid) & & & & $26.7(8.1,45.3)(n=2)$ & $11(8.4-15.7)(n=3)$ & \\
\hline waterboatman (corixid) & & & $7.5(2.3-13.6)(n=4)$ & & $11.6(1.8-23.6)(n=5)$ & \\
\hline scud & & $2.7(n=1)$ & & & & \\
\hline snail & $1.4(1.2,1.7)(n=2)$ & & $4.9(n=1)$ & $7.3(n=1)$ & $5.3(n=1)$ & \\
\hline crayfish & & $4(2.6-4.9)(n=3)$ & $5.8(n=1)$ & $10.7(n=1)$ & $12.1(8.5-15)(n=4)$ & \\
\hline dragonfly (nymphs or larvae) & & & & $12.6(n=1)$ & $10.2(12.5,7.8)(n=2)$ & $5.6(3.2,7.9)(n=2)$ \\
\hline clam (Corbicula if freshwater) & & & $7.5(6.1-8.5)(n=9)$ & & $7.6(n=1)$ & \\
\hline clam (transplanted) & & & $5.4(n=1)$ & $5.2(n=1)$ & & \\
\hline backswimmer & & & & & & $4.2(n=1)$ \\
\hline worm & & & & $14.9(n=1)$ & & \\
\hline leech & & & & $20.9(n=1)$ & & \\
\hline
\end{tabular}

Table 9. Invertebrate Se concentrations for Newport Bay. [Means and ranges are shown. $d w=$ dry weight; $n=$ number of samples.]

\begin{tabular}{|l|c|c|}
\hline species & $\begin{array}{c}\text { Upper Bay } \\
(\mu \mathrm{g} / \mathrm{g} \mathrm{dw})\end{array}$ & $\begin{array}{c}\text { Lower Bay } \\
(\mu \mathrm{g} / \mathrm{g} \mathrm{dw})\end{array}$ \\
\hline amphipod & 4.8 & none \\
\hline isopod & $8.4(6.5-10.4)$ & \\
\hline bivalve & $6.1(4.8-7.8)$ & \\
\hline clam & $2.9(2.0-3.8)$ & \\
\hline crab & $6.1(2.5-8.0)$ & \\
\hline snail & $6.2(2.3-12.0)$ & \\
\hline mussels & $4.4(4.1,4.7)$ & \\
\hline transplanted mussels & $3.9(2.7-5.3)$ & \\
\hline
\end{tabular}


Table 10. Selected particulate Se concentration (see particulate Se concentration data in CH2M Hill, 2008a, matched and 75th percentile concentrations) and a comparison of calculated invertebrate TTFs for the San Diego Creek watershed and invertebrate TTF derived from the literature. [Means and ranges are shown. Two TTFs are calculated if two particulate Se concentrations were available or chosen as representative of a site. See table 8 for invertebrate Se concentrations use in calculations of TTF. $d w=$ dry weight; $n=$ number of samples; $N A=$ not available.]

\begin{tabular}{|c|c|c|c|c|c|c|c|c|}
\hline & $\begin{array}{l}\text { Upper SDC } \\
\text { and PCW }\end{array}$ & $\begin{array}{l}\text { Marsh } \\
\text { Drains }\end{array}$ & Lower SDC & Lower PCW & IRWD wetlands & $\begin{array}{c}\text { UCl } \\
\text { wetlands }\end{array}$ & $\begin{array}{c}\text { San Diego Creek } \\
\text { watershed } \\
\text { (field average } \\
\text { by invertebrate species) }\end{array}$ & $\begin{array}{c}\text { other studies } \\
\text { (by invertebrate } \\
\text { species) } \\
\text { (See tables } 6 \text { and } 7 \\
\text { for data and } \\
\text { references) }\end{array}$ \\
\hline particulate Se $(\mu \mathrm{g} / \mathrm{g} \mathrm{dw})$ & 0.9 or 0.4 & 2.6 & 2.8 or 1.2 & 4.1 or 3.2 & 5.3 or 3.7 & 2.2 & NA & NA \\
\hline TTF-zooplankton & & & & & $\begin{array}{c}1.3 \text { or } 1.8 \\
n=1\end{array}$ & & 1.6 & $\begin{array}{l}1.5 \text { freshwater } \\
\text { zooplankton } \\
\text { composite; } \\
1.4 \text { copepod; } \\
1.3 \text { euphausiid; } \\
1.2 \text { mysid } \\
1.9 \text { daphnia }\end{array}$ \\
\hline TTF-amphipod & & & & 2.1 or $2.7 n=1$ & & & 2.4 & $\begin{array}{c}0.6 \text { marine } \\
0.94 \text { freshwater }\end{array}$ \\
\hline TTF- chironomid & & & & 2.0 or $2.5 n=1$ & 2.1 or $3.0 n=3$ & & 2.4 & 2.7 \\
\hline TTF-corixid & & & 2.7 or $6.2 n=4$ & & 2.2 or $3.1 n=5$ & & 3.6 & 2.1 \\
\hline TTF-scud & & $1.0 n=1$ & & & & & $1.0 n=1$ & $\begin{array}{l}1.4 \text { copepod; } \\
1.3 \text { euphausiid; } \\
1.2 \text { mysid; } \\
1.9 \text { daphnia }\end{array}$ \\
\hline TTF-snail & 5.6 or $3.5 n=2$ & & 1.8 or $4.1 \mathrm{n}=1$ & 1.8 or $2.3 n=1$ & 1.0 or $1.4 \mathrm{n}=1$ & & 2.7 & \\
\hline TTF-crayfish & & $1.5 n=3$ & 2.1 or $4.8 n=1$ & 2.6 or $3.3 n=1$ & 2.3 or $3.3 n=4$ & & 2.8 & 1.5 freshwater \\
\hline TTF-dragonfly (nymphs/ larvae) & & & & 3.1 or $3.9 n=1$ & 1.9 or $2.8 n=2$ & $2.5 n=2$ & 2.8 & 2.8 all insects \\
\hline TTF-clam (Corbicula) & & & 2.7 or $6.2 n=9$ & & 1.4 or $2.1 n=1$ & & 3.1 & 2.7Corbicula \\
\hline TTF-clam (transplanted) & & & 1.9 or $4.5 n=1$ & 1.3 or $1.6 n=1$ & & & $2.3 n=1$ & \\
\hline TTF-backswimmer & & & & & & $1.9 n=1$ & $1.9 n=1$ & 2.8 all insects \\
\hline TTF-worm & & & & 3.6 or $4.6 n=1$ & & & $4.1 n=1$ & \\
\hline TTF-leech & & & & 5.1 or $6.5 n=1$ & & & $5.8 n=1$ & \\
\hline
\end{tabular}


Table 11. Experimentally or field derived TTFs for fish. [Matching field datasets (temporally/spatially matched data-pairs) are used in the derivation. Unless noted, transfer is from invertebrate to fish.]

\begin{tabular}{|c|c|c|c|c|}
\hline species & kinetic TTF & field or lab TTF & experimental physiological factors & reference \\
\hline mangrove snapper & 1.1 & & ke $0.031 ;$ IR $5 \% ; 69 \%$ AE) & Xu and Wang, 2002 \\
\hline juvenile striped bass & 0.89 & & ke $0.08 ;$ IR $17 \% ; 42 \%$ AE) & Baines and others, 2002 \\
\hline mudskipper & 0.84 & & ke $0.019 ;$ IR $5 \% ; 32 \%$ AE) & $\mathrm{Ni}$ and others, 2005 \\
\hline smooth toadfish & 0.80 & & ke 0.015-0.032; IR, 7-10\%; AE 24\%) & Alquezar and others, 2008 \\
\hline fathead minnowa & $1.0^{\mathrm{b}}$ & & ke $0.025 ;$ assumed IR $5 \%$; AE 50\%) & Bennett and others, 1986 \\
\hline fathead minnow adult & $0.71-1.8^{b}$ & & ke 0.014 ;assumed IR 5\%; AE 20-50\% & Bertram and Brooks,1986 \\
\hline bluegill (fry/juvenile)a & $0.51^{b}$ & & ke $0.035 ;$ assumed IR 5\%; AE 36\%) & Besser and others, 1993 \\
\hline bluegill (fry/juvenile) & $0.61^{b}$ & & ke 0.041 ; assumed IR 5\% AE 50\%) & Cleveland and others, 1993 \\
\hline bluegill (juvenile) & & 1.15 (lab) & & Lemly, 1993 \\
\hline bluegill & & 1.06 & & Saiki and others, 1993 \\
\hline white sturgeon & & range 1.0-1.7 & & Presser and Luoma, 2006 \\
\hline mosquitofish & & 0.71-1.8 (average 1.2) & & Saiki and others, 1993 \\
\hline mosquitofish & & 1.3 & & Saiki and others, 2008 \\
\hline largemouth bass & & $1.1 ; 0.95$ (average 1.0) & & Saiki and others, 1993 \\
\hline sailfin mollie & & 1.4 & & Saiki and others, 2008 \\
\hline rainbow trout & & $0.91 ; 0.71 ; 1.1 ; 0.96$ (average 0.91) & & Casey, 2005 \\
\hline rainbow trout & & 1.04 & & $\begin{array}{l}\text { Greater Yellowstone Coalition, 2005; 2006; Hamilton and Buhl } \\
\text { 2004, 2005; Hamilton and others, } 2004\end{array}$ \\
\hline cutthroat trout & & 1.0 & & McDonald and Strosher, 1998 \\
\hline cutthroat trout from dace & & $0.87 ; 0.99$ (average 0.93 ) & & $\begin{array}{l}\text { Greater Yellowstone Coalition, 2005; 2006; Hamilton and Buhl } \\
\text { 2004, 2005; Hamilton and others, } 2004\end{array}$ \\
\hline cutthroat trout from sculpin & & $0.95 ; 1.0$ (average 0.98) & & $\begin{array}{l}\text { Greater Yellowstone Coalition, 2005; 2006; Hamilton and Buhl } \\
\text { 2004, 2005; Hamilton and others, } 2004\end{array}$ \\
\hline cutthroat trout & & $0.97 ; 1.53$ (average 1.25) & & $\begin{array}{l}\text { Greater Yellowstone Coalition, 2005; 2006; Hamilton and Buhl } \\
\text { 2004, 2005; Hamilton and others, } 2004\end{array}$ \\
\hline brook trout & & 0.77 & & Hamilton 2004a,b;2005 \\
\hline brown trout & & $1.45 ; 1.18$ (average 1.32) & & $\begin{array}{l}\text { Greater Yellowstone Coalition, 2005; 2006; Hamilton and Buhl } \\
\text { 2004, 2005; Hamilton and others, } 2004\end{array}$ \\
\hline sculpin & & $1.23 ; 1.66$ (average 1.45) & & $\begin{array}{l}\text { Greater Yellowstone Coalition, 2005; 2006; Hamilton and Buhl } \\
\text { 2004, 2005; Hamilton and others, } 2004\end{array}$ \\
\hline dace & & $1.41 ; 1.65$ (average 1.53) & & $\begin{array}{l}\text { Greater Yellowstone Coalition, 2005; 2006; Hamilton and Buhl } \\
\text { 2004, 2005; Hamilton and others, } 2004\end{array}$ \\
\hline chub & & $1.03 ; 1.38$ (average 1.21) & & $\begin{array}{l}\text { Greater Yellowstone Coalition, 2005; 2006; Hamilton and Buhl } \\
\text { 2004, 2005; Hamilton and others, } 2004\end{array}$ \\
\hline shiner & & 1.5 & & Greater Yellowstone Coalition 2005; 2006 \\
\hline whitefish & & 1.3 & & Greater Yellowstone Coalition 2005; 2006 \\
\hline sucker & & 0.97 & & Greater Yellowstone Coalition 2005; 2006 \\
\hline
\end{tabular}

a rotifer to larval fish microcosm or experimental microcosm

${ }^{b}$ with assumptions 
Table 12. Fish Se concentrations for the San Diego Creek watershed. [Means and ranges by species are shown. $d w=d r y$ weight; $n=n u m b e r$ of samples.]

\begin{tabular}{|c|c|c|c|c|c|c|}
\hline species & $\begin{array}{c}\text { Upper SDC } \\
(\mu \mathrm{g} / \mathrm{g}, \text { whole-body, } \\
\mathrm{dw})\end{array}$ & $\begin{array}{c}\text { Marsh Drains } \\
(\mu \mathrm{g} / \mathrm{g}, \mathrm{whole}-\mathrm{body} \\
\mathrm{dw})\end{array}$ & $\begin{array}{c}\text { Lower SDC } \\
(\mu \mathrm{g} / \mathrm{g}, \text { whole-body, } \\
\mathrm{dw})\end{array}$ & $\begin{array}{c}\text { Lower PCW } \\
(\mu \mathrm{g} / \mathrm{g}, \text { whole-body, dw) }\end{array}$ & $\begin{array}{c}\text { IRWD wetlands } \\
(\mu \mathrm{g} / \mathrm{g}, \text { whole-body, } \mathrm{dw})\end{array}$ & $\begin{array}{c}\text { UCl wetlands } \\
(\mu \mathrm{g} / \mathrm{g}, \text { whole-body, } \\
\mathrm{dw})\end{array}$ \\
\hline mixed fish & $\begin{array}{l}5.8 \\
n=1\end{array}$ & & $\begin{array}{c}5.5(2.4-9.0) \\
n=3\end{array}$ & & $\begin{array}{c}13 \\
n=1\end{array}$ & \\
\hline fathead minnow & & & $\begin{array}{c}9.0(8.9-9.1) \\
n=3\end{array}$ & $\begin{array}{l}6.5 \\
n=1\end{array}$ & & \\
\hline bluegill & & & $9.1(5.6-12.7) n=2$ & & & \\
\hline carp & & & $9.3(5.7-14.5) n=4$ & & $\begin{array}{l}19 \text { (dead fish filet) } \\
n=1\end{array}$ & \\
\hline red shiner & & & $\begin{array}{c}7.9(7.4-8.5) \\
n=2\end{array}$ & $\begin{array}{l}6.3 \\
n=1\end{array}$ & & \\
\hline black crappie & & & $\begin{array}{l}6.7 \\
n=1\end{array}$ & & & \\
\hline catfish & & & $\begin{array}{c}2.4(2.2-2.7) \\
n=2\end{array}$ & & & \\
\hline mosquitofish & & $\begin{array}{l}12.5 \\
n=1\end{array}$ & $\begin{array}{c}17 \\
n=1\end{array}$ & $\begin{array}{c}21 \mathrm{n}=2 \\
(12.1,29.9)\end{array}$ & $\begin{array}{c}10.1(1.3-18.9) \\
n=10\end{array}$ & $\begin{array}{c}5.8(5.6-6.0) \\
n=2\end{array}$ \\
\hline
\end{tabular}


Table 13. Invertebrate and fish Se concentrations for San Diego Creek watershed and derivation of watershed-specific TTFs for fish. [For Se concentrations, means and ranges are shown. $d w=$ dry weight; $w b=$ whole-body; $n=$ number of samples; avg = average.]

\begin{tabular}{|c|c|c|c|c|c|}
\hline $\begin{array}{l}\text { location and } \\
\text { speciation }\end{array}$ & food web & $\begin{array}{l}\text { observed Se in invertebrate } \\
(\mu \mathrm{g} / \mathrm{g} \mathrm{dw})\end{array}$ & $\begin{array}{l}\text { observed Se in fish } \\
(\mu \mathrm{g} / \mathrm{g} w b, \mathrm{dw})\end{array}$ & watershed-specific TTF & invertebrate TTF source \\
\hline $\begin{array}{l}\text { Upper SDC and PCW } \\
\text { (up to } 21 \% \text { selenite) }\end{array}$ & $\begin{array}{c}\text { sediment> } \\
\text { invertebrate> } \\
\text { fish }\end{array}$ & $\begin{array}{c}1.4 \text { snail } n=2 \\
5.8 \text { tadpole composite }\end{array}$ & no fish & & snail $=$ mollusk $=$ corbicula $=2.8$ \\
\hline Non-marsh drains & & & & & If clam, 2.8 \\
\hline Marsh drains & $\begin{array}{l}\text { sediment> } \\
\text { invertebrate> } \\
\text { fish }\end{array}$ & $\begin{array}{c}2.7 \text { scud } n=1 \\
4.0 \text { crayfish } n=3\end{array}$ & 12.5 mosquitofish $n=1$ & $\begin{array}{c}12.5 \text { mosquitofish } \\
/ 2.7 \text { amphipod=4.6 } \\
12.5 \text { mosquitofish } \\
/ 4 \text { crayfish }=3.1\end{array}$ & $\begin{array}{c}\text { crayfish=1.6; } \\
\text { scud=amphipod= } 0.9 \\
\text { average }=1.3\end{array}$ \\
\hline $\begin{array}{l}\text { Lower PCW } \\
\text { (up to } 22 \% \text { selenite) }\end{array}$ & $\begin{array}{l}\text { sediment> } \\
\text { invertebrate> } \\
\text { fish }\end{array}$ & $\begin{array}{c}8.7 \text { amphipod, } n=1 \\
27 \text { midge }(8.1 ; 45) n=2 \\
7.3 \text { snail } n=1 \\
11 \text { crayfish } n=1 \\
12.6 \text { dragonfly } n=1 \\
21 \text { leach } n=1 \\
15 \text { worm } n=1 \\
5.4 \text { trans clam } n=1 \\
\text { (all average 11) }\end{array}$ & $\begin{array}{c}6.5 \text { fathead } n=1 \\
6.3 \text { shiner } n=1 \\
21 \text { mosquitofish }(n=2)\end{array}$ & $\begin{array}{l}6.4 \text { fathead;shiner } / 8.1 \text { midge }=0.8 \\
21 \text { mosquitofish } / 11 \text { avg invert }=1.9\end{array}$ & $\begin{array}{c}\text { amphipod=0.6 } \\
\text { midge, } \\
\text { dragonfly=2.9 } \\
\text { crayfish }=1.6 \\
\text { clam }=2.8 \\
\text { leech, worm }=2.8 ? \\
\text { average }=2.1\end{array}$ \\
\hline $\begin{array}{l}\text { Lower SDC } \\
\text { (up to } 25 \% \text { selenite) }\end{array}$ & $\begin{array}{l}\text { sediment> } \\
\text { invertebrate> } \\
\text { fish }\end{array}$ & $\begin{array}{l}7.5 \text { corixid }(2.3-14) n=4 \\
5.8 \text { crayfish } n=1 \\
4.9 \text { snail } n=1 \\
7.5 \text { clam }(6.1-8.5) n=9 \\
\text { (all average } 6.4 \text { ) }\end{array}$ & $\begin{array}{l}7.8 \text { avg }(2.2-14.5) \text { bluegill, carp, fat- } \\
\text { head minnow, red shiner, } \\
\text { largemouth bass, blk crappie, wht } \\
\text { catfish, mixed fish, } n=17 \\
17 \text { mosquitofish } n=1\end{array}$ & $\begin{array}{l}7.8 \text { avg fish } / 7.5 \text { corixid }=1.04 \\
17 \text { mosquitofish } 6.4 \text { avg=2.6 }\end{array}$ & $\begin{array}{c}\text { crayfish }=1.6 \\
\text { corixid=2.9 (insect) } \\
\text { clam (freshwater) }=2.7 \\
\text { average }=2.4\end{array}$ \\
\hline $\begin{array}{l}\text { IRWD wetlands } \\
\text { (up to } 39 \% \text { selenite) }\end{array}$ & $\begin{array}{l}\text { sediment> } \\
\text { invertebrate> } \\
\text { fish }\end{array}$ & $\begin{array}{c}6.8 \text { zooplankton } n=1 \\
11 \text { midge }(8-16) n=3 \\
12 \text { corixid }(2-24) n=5 \\
5.3 \text { snail } n=1 \\
12 \text { crayfish }(8-15) n=4 \\
10 \text { dragonfly }(12 ; 7.8) \\
7.6 \text { clam } n=1 \\
\text { (all average } 9.2)\end{array}$ & $\begin{array}{c}13 \text { mixed } n=1 \\
19 \text { dead carp } n=1 \\
10 \text { mosquitofish } n=10\end{array}$ & $\begin{array}{c}13 \text { mixed } / 11.5 \text { midge, corixid=1.1 } \\
13 \text { mixed } / 9.2 \text { avg=1.4 } \\
10 \text { mosquitofish } / 9.2 \text { avg }=1.1\end{array}$ & $\begin{array}{c}\text { midge, corixid, dragon= } 2.9 \\
\text { crayfish }=1.6 \\
\text { copepod }=1.6 \\
\text { clam }=2.8 \\
\text { snail }=2.8 \\
\text { average }=2.3\end{array}$ \\
\hline $\begin{array}{l}\text { UCl wetlands } \\
\text { (up to } 100 \% \text { selenite) }\end{array}$ & $\begin{array}{c}\text { sediment> } \\
\text { invertebrate> } \\
\text { fish }\end{array}$ & $\begin{array}{c}5.6 \text { dragonfly }(3.2 ; 7.9) \\
4.2 \text { back-swimmer } n=1 \\
\text { (4.9 average) }\end{array}$ & 5.8 mosquitofish $n=2$ & 5.8 mosquitofish $/ 4.9=1.2$ & aquatic insects $=2.9$ \\
\hline $\begin{array}{l}\text { Santa Ana Delhi } \\
\text { Channel } \\
\text { (up to } 11 \% \text { selenite) }\end{array}$ & $\begin{array}{l}\text { sediment> } \\
\text { invertebrate }\end{array}$ & 4.3 clam $n=1$ & & & clam $=2.8$ \\
\hline
\end{tabular}


Table 14. Invertebrate and fish Se concentrations for Newport Bay and derivation of bay-specific TTFs for fish. [Means and ranges are shown. The percentage of food items in diets of specific fish species also are given. $d w=d r y$ weight; $w b=$ whole-body; $n=$ number of samples .

\begin{tabular}{|c|c|c|c|c|c|}
\hline species & $\begin{array}{c}\text { Upper Bay } \\
(\mu g / g, w b, d w)\end{array}$ & $\begin{array}{c}\text { Lower Bay } \\
(\mu \mathrm{g} / \mathrm{g}, \mathrm{wb}, \mathrm{dw})\end{array}$ & $\begin{array}{l}\% \text { in diet (Allen and others, } \\
\text { 2008) }\end{array}$ & $\begin{array}{c}\text { Upper Bay invertebrate } \\
\mu \mathrm{g} / \mathrm{g} d w \text { (clapper rail study)a }\end{array}$ & TTF \\
\hline striped mullet & $5.5(2.4-9.5) \quad n=7$ & & $\begin{array}{l}\text { copepod } 78 \% \\
\text { (bivalve } 13 \% \text { ) }\end{array}$ & & \\
\hline California killifish & $5.8(2.6-9.5) n=5$ & $\begin{array}{c}3.9(1.6-4.6) \\
n=9\end{array}$ & $\begin{array}{l}\text { bivalve } 62 \% \\
* * \text { isopod } 3 \%\end{array}$ & $\begin{array}{c}6.1 \text { bivalve } n=5 \\
2.9 \text { clam } n=4 \\
4.4 \text { mussel } n=2 \\
4.5 \text { average } \\
8.4 \text { isopod }\end{array}$ & $5.8 / 4.5=1.3$ \\
\hline shadow goby & $5.1 n=1$ & & amphipod $70 \%$ & amphipod $4.8 n=1$ & $5.1 / 4.8=1.1$ \\
\hline arrow goby & $4.0(1.8-8.0) n=4$ & $1.6 n=1$ & copepod 94\% & & \\
\hline cheekspot goby & & $2.3(1.4-3.3) n=2$ & copepod 70\% & & \\
\hline anchovy & $3.0(3.0-3.1) n=2$ & & amphipod 99\% & amphipod $4.8 n=1$ & $3.0 / 4.8=0.62$ \\
\hline barred sandbass & & $2.2(2.2,2.2) n=2$ & & & \\
\hline spotted sandbass & $3.2(3.1-3.4) n=2$ & & $\begin{array}{c}\text { fish } 32 \% \\
\text { bivalve } 26 \% \\
\text { crab } 15 \%\end{array}$ & $\begin{array}{c}\text { assume fish } 3.0 \\
\text { bivalve } 6.1 \mathrm{n}=5 \\
\text { crab } 6.1 \mathrm{n}=5\end{array}$ & $3.2 / 4.6=0.70$ \\
\hline diamond turbot & $3.3(2.4-4.0) n=3$ & $2.7(1.5-4.0) n=2$ & & & \\
\hline California halibut & $4.0(3.4-4.5) n=4$ & $1.5(0.9-3.1) n=4$ & $\begin{array}{c}\text { mysid } 90 \% \text { (eating from } \\
\text { water column) }\end{array}$ & & \\
\hline staghorn sculpin & $1.6 n=1$ & $2.0(1.6-2.4) n=3$ & & & \\
\hline black surfperch & & $1.1(1.0-1.2) n=3$ & & & \\
\hline shiner perch & & $1.2(1.2,1.2) n=2$ & & & \\
\hline pile surfperch & $1.8(1.7-1.8) n=2$ & $1.7 n=1$ & & & \\
\hline topsmelt & $3.4(1.7-8.0) n=24$ & $2.6(1.3-4.1) n=26$ & $\begin{array}{c}\text { copepod } 57 \% \\
\text { bivalve } 31 \%\end{array}$ & $\begin{array}{c}4.5 \text { average of bivalve, } \\
\text { clam, mussel }\end{array}$ & \\
\hline
\end{tabular}

${ }^{a}$ other data: $6.2 \mu \mathrm{g} / \mathrm{g}$ snail $(\mathrm{n}=15)$

${ }^{\mathrm{b}}$ killifish is the only fish that eats isopods (with highest Se in invertebrates, $8.4 \mu \mathrm{g} / \mathrm{g} \mathrm{dw}$ ) 
Table 15. Mean and ranges for bird egg Se concentrations for the San Diego Creek watershed. [dw = dry weight; $n=$ number of samples.]

\begin{tabular}{|l|c|c|c|}
\hline species & $\begin{array}{c}\text { Lower SDC } \\
(\mu \mathrm{g} / \mathrm{g}, \text { bird egg dw })\end{array}$ & $\begin{array}{c}\text { IRWD wetlands } \\
(\mu \mathrm{g} / \mathrm{g}, \text { bird egg, dw })\end{array}$ & $\begin{array}{c}\text { UCl wetlands } \\
(\mu \mathrm{g} / \mathrm{g}, \mathrm{bird} \text { egg, } \mathrm{dw})\end{array}$ \\
\hline American avocet & $2.8(1.9-3.9) \mathrm{n}=3^{*}$ & $\begin{array}{c}6.4(2.0-17.2) \\
\mathrm{n}=8\end{array}$ & $\begin{array}{c}5.1(3.3-11) \\
\mathrm{n}=5\end{array}$ \\
\hline black-necked stilt & $6.9(3.6-8.7) \mathrm{n}=11$ & $\begin{array}{c}5.0(3.0-9.8) \\
\mathrm{n}=4\end{array}$ & \\
\hline killdeer & $9.5(9.1-9.9) \mathrm{n}=2$ & $\begin{array}{c}4.8(2.6-7.1) \\
\mathrm{n}=2\end{array}$ & \\
\hline American coot & 5.2 & & $\begin{array}{c}2.7(1.9-4.5) \\
\mathrm{n}=9\end{array}$ \\
\hline mallard & $\mathrm{n}=1$ & $6.2(4.0-7.0)$ & $\mathrm{n}=4$ \\
\hline pied-billed grebe & 5.8 & & $\begin{array}{c}6.2(4.0-11) \\
\mathrm{n}=4\end{array}$ \\
\hline
\end{tabular}

Table 16. Mean and ranges for bird egg Se concentrations for Upper Newport Bay [dw = dry weight; $n=$ number of samples.]

\begin{tabular}{|c|c|}
\hline species & $\begin{array}{c}\text { Upper Bay } \\
(\mu \mathrm{g} / \mathrm{g}, \text { bird egg, } \mathrm{dw})\end{array}$ \\
\hline American avocet & $\begin{array}{c}5.3(1.6-10.7) \\
n=12\end{array}$ \\
\hline clapper rail & $\begin{array}{c}3.7(3.1-4.5) \\
n=6\end{array}$ \\
\hline black-necked stilt & $\begin{array}{c}5.1(3.4-8.5) \\
n=3\end{array}$ \\
\hline killdeer & $\begin{array}{c}2.6(2.3-2.9) \\
n=2\end{array}$ \\
\hline tern & $\begin{array}{c}4.4(2.5-8.4) \\
n=18\end{array}$ \\
\hline black skimmer & $\begin{array}{c}3.1(2.1-5.6) \\
n=21\end{array}$ \\
\hline
\end{tabular}

Table 17. Calculated TTFs from laboratory mallard studies; the endpoint is reduced hatchability in eggs (see Ohlendorf, 2003 for complete dataset). [Selenium concentrations in diet and bird eggs used to calculate TTFs also are shown. $d w=$ dry weight; $n$ $=$ number of samples; $E C=$ effect concentration.]

\begin{tabular}{|c|c|c|}
\hline TTF & diet, $\mu \mathrm{g} / \mathrm{g} \mathrm{dw}$ & bird egg, $\mu \mathrm{g} / \mathrm{g} \mathrm{dw}$ \\
\hline 1.8 & $3.6(\mathrm{EC} 3)$ & 6.4 \\
\hline 2.55 & $4.9(\mathrm{EC} 10)$ & 12.5 \\
\hline 2.9 & $5.7(\mathrm{EC} 18)$ & 16.5 \\
\hline
\end{tabular}


Table 18. Modeled Se exposure for the San Diego Creek watershed and Newport Bay. [Two scenarios are shown: scenario A: particulate to invertebrate to average fish to bird; and scenario B: particulate to invertebrate to mosquitofish to bird. The modeled Se criterion is $8.0 \mu \mathrm{g} / \mathrm{g}$ in bird eggs (dw). $\mathrm{dw}=\mathrm{dry}$ weight; $w b=$ whole-body; $n=$ number of samples; $N A=$ not applicable.]

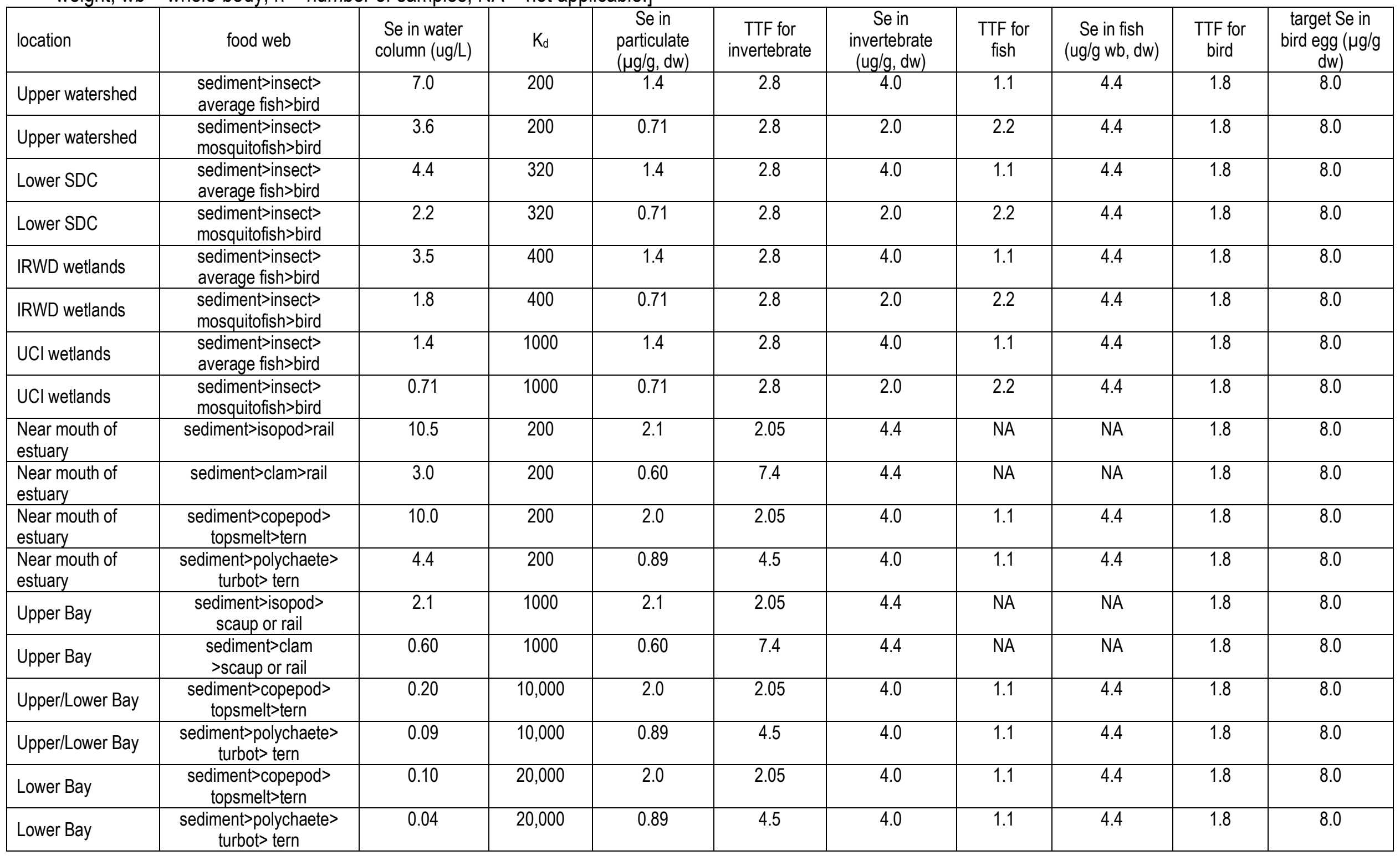


Table 19. Modeled Se exposure for the San Diego Creek watershed and Newport Bay. [The modeled scenario is particulate to invertebrate to bird. The modeled Se criterion is $8.0 \mu \mathrm{g} / \mathrm{g}$ in bird eggs ( $\mathrm{dw}) . \mathrm{dw}=$ dry weight; $\mathrm{n}=$ number of samples.]

\begin{tabular}{|c|c|c|c|c|c|c|c|c|}
\hline location & food web & $\begin{array}{c}\text { Se in water } \\
\text { column (ug/L) }\end{array}$ & $\mathrm{K}_{\mathrm{d}}$ & $\begin{array}{c}\text { Se in particulate } \\
(\mu \mathrm{g} / \mathrm{g}, \mathrm{dw})\end{array}$ & $\begin{array}{c}\text { TTF for } \\
\text { invertebrate }\end{array}$ & $\begin{array}{c}\text { Se in invertebrate } \\
(\mathrm{ug} / \mathrm{g}, \mathrm{dw})\end{array}$ & TTF for bird & $\begin{array}{c}\text { target Se in bird } \\
\text { egg }(\mu g / g d w)\end{array}$ \\
\hline Upper watershed & sediment>insect>>bird & 8.0 & 200 & 1.6 & 2.8 & 4.4 & 1.8 & 8.0 \\
\hline Lower SDC & sediment>insect>>bird & 5.0 & 320 & 1.6 & 2.8 & 4.4 & 1.8 & 8.0 \\
\hline IRWD wetlands & sediment>insect>>bird & 4.0 & 400 & 1.6 & 2.8 & 4.4 & 1.8 & 8.0 \\
\hline UCI wetlands & sediment>insect>>bird & 1.6 & 1000 & 1.6 & 2.8 & 4.4 & 1.8 & 8.0 \\
\hline $\begin{array}{l}\text { Near mouth of } \\
\text { estuary }\end{array}$ & sediment>isopod>rail & 10.5 & 200 & 2.1 & 2.05 & 4.4 & 1.8 & 8.0 \\
\hline $\begin{array}{l}\text { Near mouth of } \\
\text { estuary }\end{array}$ & sediment $>$ clam $>$ rail & 3.0 & 200 & 0.60 & 7.4 & 4.4 & 1.8 & 8.0 \\
\hline $\begin{array}{l}\text { Near mouth of } \\
\text { estuary }\end{array}$ & sediment>copepod>bird & 10.05 & 200 & 2.1 & 2.05 & 4.4 & 1.8 & 8.0 \\
\hline $\begin{array}{l}\text { Near mouth of } \\
\text { estuary }\end{array}$ & sediment $>$ polychaete $>$ bird & 4.9 & 200 & 0.98 & 4.5 & 4.4 & 1.8 & 8.0 \\
\hline Upper Bay & sediment>isopod>scaup or rail & 2.1 & 1000 & 2.1 & 2.05 & 4.4 & 1.8 & 8.0 \\
\hline Upper Bay & sediment>clam>scaup or rail & 0.60 & 1000 & 0.60 & 7.4 & 4.4 & 1.8 & 8.0 \\
\hline Upper/Lower Bay & sediment>copepod>bird & 0.21 & 10,000 & 2.1 & 2.05 & 4.4 & 1.8 & 8.0 \\
\hline Upper/Lower Bay & sediment>polychaete>bird & 0.098 & 10,000 & 0.98 & 4.5 & 4.4 & 1.8 & 8.0 \\
\hline Lower Bay & sediment>copepod>bird & 0.105 & 20,000 & 2.1 & 2.05 & 4.4 & 1.8 & 8.0 \\
\hline Lower Bay & sediment>polychaete>bird & 0.049 & 20,000 & 0.98 & 4.5 & 4.4 & 1.8 & 8.0 \\
\hline
\end{tabular}


Table 20. Modeled Se exposure for the San Diego Creek watershed and Newport Bay. [Two scenarios are modeled: scenario A: particulate to invertebrate to average fish; and scenario B: particulate to invertebrate to forage fish to predator fish. The modeled Se guideline is $5.0 \mu \mathrm{g} / \mathrm{g}$ in fish tissue (wb, dw). $d w=d r y$ weight; $w b=$ whole-body; $n=$ number of samples; $N A=$ not applicable.]

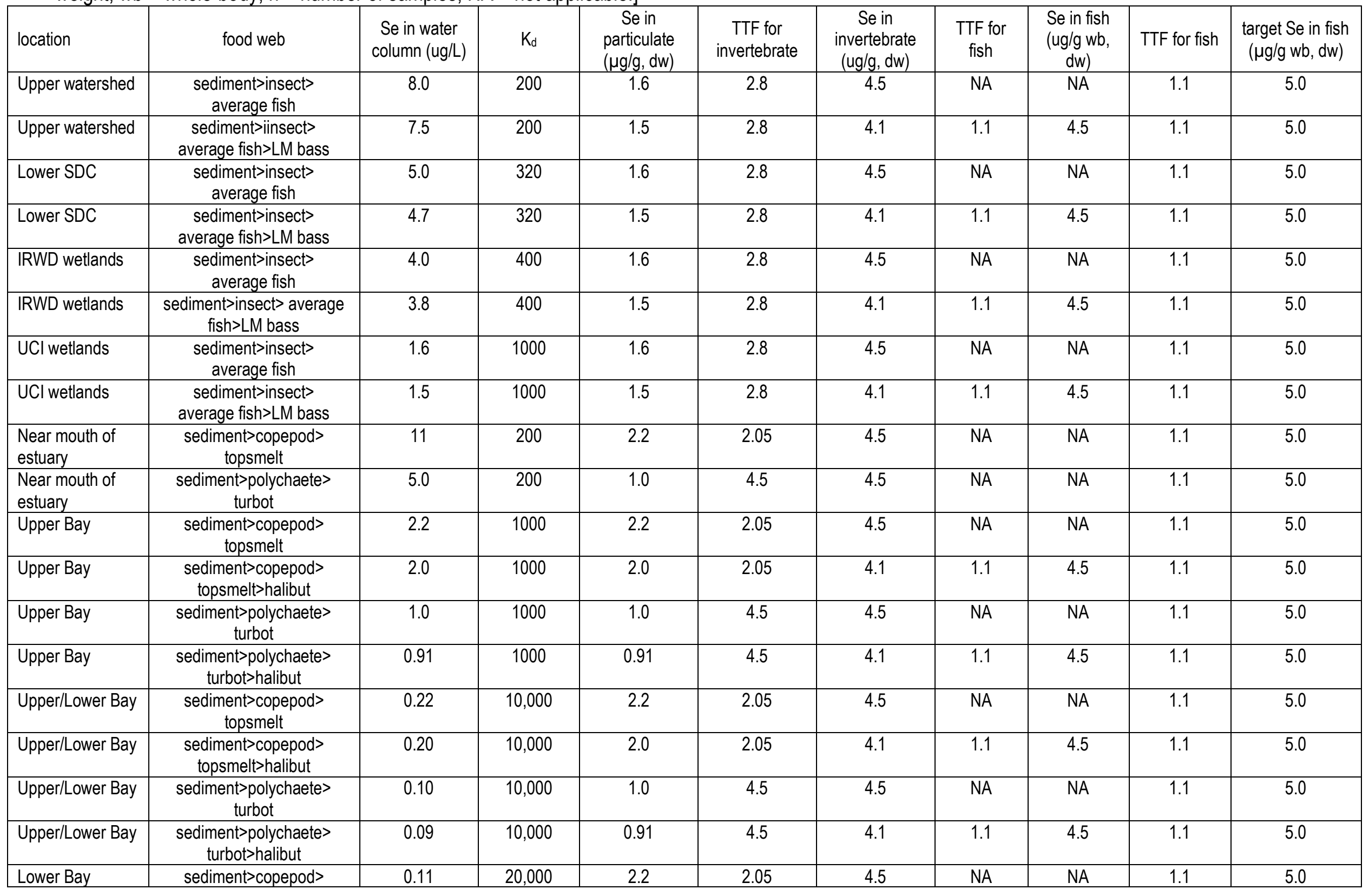




\begin{tabular}{|c|c|c|c|c|c|c|c|c|c|c|}
\hline location & food web & $\begin{array}{l}\text { Se in water } \\
\text { column (ug/L) }\end{array}$ & $\mathrm{K}_{\mathrm{d}}$ & $\begin{array}{c}\text { Se in } \\
\text { particulate } \\
(\mu \mathrm{g} / \mathrm{g}, \mathrm{dw})\end{array}$ & $\begin{array}{c}\text { TTF for } \\
\text { invertebrate }\end{array}$ & $\begin{array}{c}\text { Se in } \\
\text { invertebrate } \\
\text { (ug/g, dw) }\end{array}$ & $\begin{array}{l}\text { TTF for } \\
\text { fish }\end{array}$ & $\begin{array}{c}\text { Se in fish } \\
\text { (ug/g wb, } \\
d w)\end{array}$ & TTF for fish & $\begin{array}{l}\text { target Se in fish } \\
(\mu \mathrm{g} / \mathrm{g} w b, \mathrm{dw})\end{array}$ \\
\hline & topsmelt & & & & & & & & & \\
\hline Lower Bay & $\begin{array}{c}\text { sediment>copepod> } \\
\text { topsmelt>halibut }\end{array}$ & 0.10 & 20,000 & 2.0 & 2.05 & 4.1 & 1.1 & 4.5 & 1.1 & 5.0 \\
\hline Lower Bay & $\begin{array}{c}\text { sediment>polychaete> } \\
\text { turbot }\end{array}$ & 0.05 & 20,000 & 1.0 & 4.5 & 4.5 & NA & NA & 1.1 & 5.0 \\
\hline Lower Bay & $\begin{array}{c}\text { sediment>polychaete> } \\
\text { turbot>halibut }\end{array}$ & 0.046 & 20,000 & 0.91 & 4.5 & 4.1 & 1.1 & 4.5 & 1.1 & 5.0 \\
\hline
\end{tabular}


Table 21. Generalized modeled Se exposure scenarios for the watershed based on protection for fish. [dw = dry weight.]

\begin{tabular}{|c|c|c|c|c|c|c|}
\hline $\begin{array}{l}\text { Se guideline for } \\
\text { fish }(\mu \mathrm{g} / \mathrm{g} \mathrm{dw})\end{array}$ & TTF for fish & $\begin{array}{l}\text { Se in invertebrate } \\
(\mu \mathrm{g} / \mathrm{g} \mathrm{dw})\end{array}$ & TTF for aquatic insect & $\begin{array}{c}\text { Se in particulate } \\
(\mu \mathrm{g} / \mathrm{g} \mathrm{dw})\end{array}$ & $\mathrm{K}_{\mathrm{d}}$ & $\begin{array}{c}\text { Se in water column } \\
(\mathrm{ug} / \mathrm{L})\end{array}$ \\
\hline \multicolumn{7}{|c|}{ Effect of varying $K_{d}$} \\
\hline 5 & 1.1 & 4.55 & 2.8 & 1.62 & 136 (median) & 11.94 \\
\hline 5 & 1.1 & 4.55 & 2.8 & 1.62 & 168 (mean) & 9.66 \\
\hline 5 & 1.1 & 4.55 & 2.8 & 1.62 & 238 (75th percentile) & 6.82 \\
\hline 5 & 1.1 & 4.55 & 2.8 & 1.62 & 400 (wetland A) & 4.06 \\
\hline 5 & 1.1 & 4.55 & 2.8 & 1.62 & 800 (wetland B) & 2.03 \\
\hline 5 & 1.1 & 4.55 & 2.8 & 1.62 & 791 (UCl wetland mean) & 2.05 \\
\hline \multicolumn{7}{|c|}{ Effect of varying fish guideline } \\
\hline 8 & 1.1 & 7.27 & 2.8 & 2.60 & 136 (median) & 19.10 \\
\hline 7 & 1.1 & 6.36 & 2.8 & 2.27 & 136 (median) & 16.71 \\
\hline 6 & 1.1 & 5.45 & 2.8 & 1.95 & 136 (median) & 14.32 \\
\hline 5 & 1.1 & 4.55 & 2.8 & 1.62 & 136 (median) & 11.94 \\
\hline \multicolumn{7}{|c|}{ Effect of varying fish guideline at a 75th percentile $\mathrm{K}_{d}$} \\
\hline 8 & 1.1 & 7.27 & 2.8 & 2.60 & 238 (75th percentile) & 10.91 \\
\hline 5 & 1.1 & 4.55 & 2.8 & 1.62 & 238 (75th percentile) & 6.82 \\
\hline
\end{tabular}


Table 22. Generalized modeled exposure scenarios for the watershed based on protection of birds. [dw = dry weight]

\begin{tabular}{|c|c|c|c|c|c|c|c|c|}
\hline $\begin{array}{l}\text { Se guideline for bird egg } \\
(\mu \mathrm{g} / \mathrm{g} \mathrm{dw})\end{array}$ & $\begin{array}{c}\text { TTF for } \\
\text { bird }\end{array}$ & $\begin{array}{l}\text { Se in fish } \\
(\mu g / g d w)\end{array}$ & $\begin{array}{l}\text { TTF for } \\
\text { fish }\end{array}$ & $\begin{array}{l}\text { Se in invertebrate } \\
(\mu \mathrm{g} / \mathrm{g} \mathrm{dw})\end{array}$ & $\begin{array}{c}\text { TTF for aquatic } \\
\text { insect }\end{array}$ & $\begin{array}{c}\text { Se in particulate } \\
(\mu \mathrm{g} / \mathrm{g} \mathrm{dw})\end{array}$ & $\mathrm{K}_{\mathrm{d}}$ & $\begin{array}{c}\text { Se in water column } \\
\text { (ug/L) }\end{array}$ \\
\hline 8 & 1.8 & 4.44 & 1.1 & 4.04 & 2.8 & 1.44 & 136 (median) & 10.61 \\
\hline 8 & 1.8 & 4.44 & 1.1 & 4.04 & 2.8 & 1.44 & 238 (75th percentile) & 6.06 \\
\hline 8 & 1.8 & 4.44 & 1.1 & 4.04 & 2.8 & 1.44 & 400 (wetland A) & 3.61 \\
\hline 8 & 1.8 & 4.44 & 1.1 & 4.04 & 2.8 & 1.44 & 800 (wetland B) & 1.80 \\
\hline 12.5 & 1.8 & 6.94 & 1.1 & 6.31 & 2.8 & 2.25 & 136 (median) & 16.58 \\
\hline 12.5 & 1.8 & 6.94 & 1.1 & 6.31 & 2.8 & 2.25 & 238 (75th percentile) & 9.47 \\
\hline \multicolumn{9}{|c|}{ Effect of varying TTF for bird } \\
\hline 8 & 1.6 & 5.00 & 1.1 & 4.55 & 2.8 & 1.62 & 238 (75th percentile) & 6.82 \\
\hline 8 & 1.6 & 5.00 & 1.1 & 4.55 & 2.8 & 1.62 & 136 (median) & 11.94 \\
\hline
\end{tabular}


Table 23. Model validation for Newport Bay showing predicted and observed fish Se concentrations. [SPM = suspended particulate material; $\max =$ maximum; $\mathrm{d} w=$ dry weight; $\mathrm{n}=$ number of samples.]

\begin{tabular}{|c|c|c|c|c|c|c|c|}
\hline food web & $\begin{array}{c}\text { Se in } \\
\text { particulate } \\
(\mu \mathrm{g} / \mathrm{g} \mathrm{dw})\end{array}$ & $\begin{array}{c}\text { TTF for } \\
\text { invertebrate }\end{array}$ & $\begin{array}{l}\text { predicted Se in } \\
\text { invertebrate } \\
(\mu \mathrm{g} / \mathrm{g} \mathrm{dw})\end{array}$ & $\begin{array}{l}\text { TTF for } \\
\text { fish }\end{array}$ & $\begin{array}{c}\text { predicted Se in } \\
\text { fish } \\
(\mu \mathrm{g} / \mathrm{g}, \mathrm{wb}, \mathrm{dw})\end{array}$ & $\begin{array}{l}\text { observed Se in } \\
\text { fish } \\
\text { (mean } \mu g / g, w b \text {, } \\
d w \text { ) }\end{array}$ & $\begin{array}{l}\text { observed Se } \\
\text { range in fish } \\
(\mu \mathrm{g} / \mathrm{g}, \mathrm{wb}, \mathrm{dw})\end{array}$ \\
\hline \multicolumn{8}{|c|}{ Upper Bay } \\
\hline mean SPM>copepod>topsmelt & 0.21 & 2.05 & 0.43 & 1.1 & 0.47 & 3.4 & $2.4-9.5 n=7$ \\
\hline max SPM>copepod>topsmelt & 1.00 & 2.05 & 2.05 & 1.1 & 2.26 & & \\
\hline mean SPM>polychaete>turbot & 0.21 & 4.5 & 0.94 & 1.1 & 1.03 & 3.3 & $2.4-4.0 n=3$ \\
\hline $\max \mathrm{SPM}>$ polychaete>turbot & 1.00 & 4.5 & 4.5 & 1.1 & 5.0 & & \\
\hline mean SPM>polychaete>killifish & 0.21 & 4.5 & 0.94 & 1.1 & 1.03 & 5.8 & $2.6-9.5 n=5$ \\
\hline max SPM> polychaete>killifish & 1.00 & 4.5 & 4.5 & 1.1 & 5.0 & & \\
\hline mean SPM>clams>turbot & 0.21 & 7.40 & 1.55 & 1.1 & 1.71 & 3.3 & $2.4-4.0 n=3$ \\
\hline creekSPM>clams>turbot & 1.00 & 7.40 & 7.40 & 1.1 & 8.14 & & \\
\hline meanSPM>anchovy>halibut & 0.21 & 1.70 & 0.36 & 1.1 & 0.39 & 4.0 & $3.4-4.5 n=4$ \\
\hline meanSPM>anchovy>halibut & 1.00 & 1.70 & 1.70 & 1.1 & 1.87 & & \\
\hline sediments>mullet & 2.00 & & & 2.0 & 4.00 & 5.5 & $2.4-9.5 n=7$ \\
\hline \multicolumn{8}{|c|}{ Lower Bay } \\
\hline sediments>amphipods>killifish & 1.10 & 0.60 & 0.66 & 1.1 & 0.73 & 3.9 & $1.6-4.6 n=9$ \\
\hline sediments>amphipods>killifish & 2.98 & 0.60 & 1.79 & 1.1 & 1.97 & & \\
\hline sediment>copepod>topsmelt>halibut & 1.10 & 2.05 and 1.1 & 2.50 & 1.1 & 2.75 & 1.5 & $0.9-3.1 n=4$ \\
\hline sediment>copepod>topsmelt>halibut & 2.98 & 2.05 and 1.1 & 6.70 & 1.1 & 7.40 & 1.5 & \\
\hline sediment>polychaete>turbot & 1.1 & 4.5 & 5.0 & 1.1 & 5.5 & 2.7 & $1.5-4.0 n=2$ \\
\hline sediment>polychaete>turbot & 2.98 & 4.5 & 13.4 & 1.1 & 14.7 & & \\
\hline
\end{tabular}


Table 24. Model validation for bay showing (1) predicted and observed fish Se concentrations and (2) predicted and observed bird egg Se concentrations. [SPM = suspended particulate material; $\max =$ maximum; $d w=$ dry weight; $n=$ number of samples; $N A=$ not available.]

\begin{tabular}{|c|c|c|c|c|c|c|c|c|c|c|}
\hline food web & $\begin{array}{c}\text { Se in } \\
\text { particulate } \\
(\mu g / g d w)\end{array}$ & $\begin{array}{c}\text { TTF for } \\
\text { invertebrate }\end{array}$ & $\begin{array}{c}\text { predicted Se } \\
\text { in } \\
\text { invertebrate } \\
(\mu \mathrm{g} / \mathrm{g} \mathrm{dw}) \\
\end{array}$ & $\begin{array}{l}\text { TTF for } \\
\text { fish }\end{array}$ & $\begin{array}{c}\text { predicted Se in } \\
\text { fish } \\
(\mu \mathrm{g} / \mathrm{g}, w b, d w)\end{array}$ & $\begin{array}{l}\text { observed Se } \\
\text { in fish } \\
\text { (mean } \mu g / g, \\
\text { wb, dw) }\end{array}$ & $\begin{array}{l}\text { TTF for } \\
\text { bird }\end{array}$ & $\begin{array}{l}\text { predicted Se } \\
\text { in bird egg, } \\
(\mu \mathrm{g} / \mathrm{g} \mathrm{dw})\end{array}$ & $\begin{array}{c}\text { observed Se in } \\
\text { bird egg ( } \mu \mathrm{g} / \mathrm{g} \\
\mathrm{dw})^{\mathrm{a}} \\
\text { (skimmer/tern) }^{\text {(skme }}\end{array}$ & $\begin{array}{c}\text { Se in bird } \\
\text { egg from } \\
\text { observed fish } \\
(\mu g / g d w)\end{array}$ \\
\hline $\begin{array}{l}\text { mean SPM>copepod>topsmelt> } \\
\text { skimmer, tern, grebe }\end{array}$ & 0.21 & 2.05 & 0.43 & 1.1 & 0.47 & 3.4 & 1.8 & 0.85 & $3.1 / 4.4$ & 6.1 \\
\hline max SPM & 1.00 & 2.05 & 2.05 & 1.1 & 2.26 & & 1.8 & 4.07 & $3.1 / 4.4$ & \\
\hline $\max$ SPM & 1.00 & 4.5 & 4.5 & 1.1 & 5.0 & & 1.8 & 9.0 & $3.1 / 4.4$ & \\
\hline $\begin{array}{l}\text { mean SPM>polychaete>killifish> } \\
\text { skimmer, tern, grebe }\end{array}$ & 0.21 & 4.5 & 0.94 & 1.1 & 1.03 & 5.8 & 1.8 & 1.85 & $3.1 / 4.4$ & 10.4 \\
\hline $\max$ SPM & 1.00 & 4.5 & 4.5 & 1.1 & 5.0 & & 1.8 & 9.0 & $3.1 / 4.4$ & \\
\hline $\begin{array}{l}\text { mean SPM>clams>turbot> } \\
\text { skimmer, tern, grebe }\end{array}$ & 0.21 & 7.40 & 1.55 & 1.1 & 1.71 & 3.3 & 1.8 & 3.1 & $3.1 / 4.4$ & 5.9 \\
\hline $\begin{array}{l}\text { mean SPM>anchovy>halibut> } \\
\text { skimmer, ern, grebe }\end{array}$ & 0.21 & 1.70 & 0.36 & 1.1 & 0.39 & 4.0 & 1.8 & 0.70 & $3.1 / 4.4$ & 7.2 \\
\hline $\max$ SPM & 1.00 & 1.70 & 1.70 & 1.1 & 1.87 & & 1.8 & 3.4 & $3.1 / 4.4$ & \\
\hline $\begin{array}{l}\text { mean sediment>mullet> skimmer, } \\
\text { tern, grebe }\end{array}$ & 2.00 & & & 2.0 & 4.00 & 5.5 & 1.8 & 7.2 & $3.1 / 4.4$ & 9.9 \\
\hline \multicolumn{11}{|c|}{ Lower Bay } \\
\hline $\begin{array}{l}\text { sediment>amphipods>killifish> } \\
\text { skimmer, tern, grebe }\end{array}$ & 1.10 & 0.60 & 0.66 & 1.1 & 0.73 & 3.9 & 1.8 & 1.31 & $3.1 / 4.4$ & 7.0 \\
\hline max sediment & 2.98 & 0.60 & 1.79 & 1.1 & 1.97 & & 1.8 & 3.54 & $3.1 / 4.4$ & \\
\hline $\begin{array}{l}\text { sediment>copepod>topsmelt> } \\
\text { halibut>pelican, osprey }\end{array}$ & 1.10 & 2.05 and 1.1 & 2.50 & 1.1 & 2.75 & 1.5 & 1.8 & 4.95 & $3.1 / 4.4$ & 2.7 \\
\hline max sediment & 2.98 & 2.05 and 1.1 & 6.70 & 1.1 & 7.40 & 1.5 & 1.8 & 13.32 & $3.1 / 4.4$ & \\
\hline $\begin{array}{l}\text { sediment>polychaete>turbot> } \\
\text { skimmer, tern, grebe }\end{array}$ & 1.1 & 4.5 & 5.0 & 1.1 & 5.5 & 2.7 & 1.8 & 9.9 & $3.1 / 4.4$ & 4.9 \\
\hline max sediment & 2.98 & 4.5 & 13.4 & 1.1 & 14.7 & & 1.8 & 26.5 & $3.1 / 4.4$ & \\
\hline sediment & 2.00 & & & 2.0 & 4.00 & 5.5 & 1.8 & 7.2 & $3.1 / 4.4$ & \\
\hline
\end{tabular}

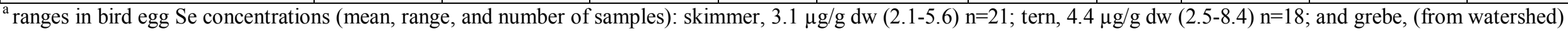
$6.1 \mu \mathrm{g} / \mathrm{g} \mathrm{dw}(4-11) \mathrm{n}=5$ 
Table 25. Model validation for bay showing predicted and observed bird egg Se concentrations. [dw = dry weight; $n=$ number of samples.]

\begin{tabular}{|c|c|c|c|c|c|c|c|c|}
\hline food web & $\begin{array}{c}\text { particulate } \\
\mathrm{Se}(\mu \mathrm{g} / \mathrm{g} d w)\end{array}$ & $\begin{array}{c}\text { TTF for } \\
\text { invertebrate }\end{array}$ & $\begin{array}{c}\text { predicted Se } \\
\text { in } \\
\text { invertebrate } \\
(\mu \mathrm{g} / \mathrm{g} \mathrm{dw})\end{array}$ & $\begin{array}{l}\text { TTF for } \\
\text { bird }\end{array}$ & $\begin{array}{c}\text { predicted } \\
\text { Se in bird } \\
\text { egg } \\
(\mu \mathrm{g} / \mathrm{g}, \mathrm{dw})\end{array}$ & $\begin{array}{l}\text { observed } \\
\text { Se in bird } \\
\text { egga } \\
(\mu \mathrm{g} / \mathrm{g}, \mathrm{dw})\end{array}$ & $\begin{array}{l}\text { Se in bird egg } \\
\text { (range, } \mu g / g, \\
\text { egg dw) }\end{array}$ & $\begin{array}{c}\text { number of } \\
\text { samples }\end{array}$ \\
\hline \multicolumn{9}{|c|}{ Upper Bay } \\
\hline mean SPM>isopod>avocet & 0.21 & 2.05 & 0.43 & 1.80 & 0.77 & 5.35 & $(1.6-10.7)$ & $n=12$ \\
\hline creekSPM>isopod>avocet & 1.00 & 2.05 & 2.05 & 1.80 & 3.69 & 5.35 & & \\
\hline mean SPM>isopod>rail & 0.21 & 2.05 & 0.43 & 1.80 & 0.77 & 3.7 & $(3.1-4.5)$ & $n=6$ \\
\hline creekSPM>isopod>rail & 1.00 & 2.05 & 2.05 & 1.80 & 3.69 & 3.7 & & \\
\hline mean SPM>clams>scaup & 0.21 & 7.40 & 1.55 & 1.80 & 2.80 & NA & & \\
\hline creekSPM>clams>scaup & 1.00 & 7.40 & 7.40 & 1.80 & 13.32 & NA & & \\
\hline mean SPM>clams>rail & 0.21 & 7.40 & 1.55 & 1.80 & 2.80 & 3.7 & $(3.1-4.5)$ & $n=6$ \\
\hline creekSPM>clams>rail & 1.00 & 7.40 & 7.40 & 1.80 & 13.32 & 3.7 & & \\
\hline \multicolumn{9}{|c|}{ Lower Bay } \\
\hline sediment>clam>scaup & 1.1 & 7.40 & 8.14 & 1.80 & 14.65 & NA & & \\
\hline sediment>clam>scaup & 2.98 & 7.40 & 22.05 & 1.80 & 39.69 & NA & & \\
\hline sediment>clam>scaup & 2 & 7.40 & 14.80 & 1.80 & 26.64 & NA & & \\
\hline sediment>clam>scaup & 2 & 7.40 & 14.80 & 1.80 & 26.64 & NA & & \\
\hline
\end{tabular}

${ }^{a}$ additional bird egg Se concentrations (mean, range, and number of samples): stilt, $5.1 \mu \mathrm{g} / \mathrm{g} \mathrm{dw}(3.4-8.5$ ) (n=3); and killdeer,

$2.6 \mu \mathrm{g} / \mathrm{g} \mathrm{dw}(2.3-2.9)(\mathrm{n}=2)$ 
Table 26. Model validation for watershed showing (1) predicted and observed invertebrate Se concentrations and (2) predicted and observed bird egg Se concentrations. [dw = dry weight; $n=$ number of samples]

\begin{tabular}{|c|c|c|c|c|c|c|c|c|c|c|}
\hline location & food web & invertebrate & $\begin{array}{c}\text { Se in } \\
\text { particulate } \\
(\mu \mathrm{g} / \mathrm{g} \mathrm{dw})\end{array}$ & $\begin{array}{c}\text { TTF for } \\
\text { invertebrate }\end{array}$ & $\begin{array}{l}\text { predicted Se in } \\
\text { invertebrate } \\
(\mu \mathrm{g} / \mathrm{g} \mathrm{dw})\end{array}$ & $\begin{array}{l}\text { observed in } \\
\text { invertebrate } \\
\text { (average) }\end{array}$ & $\begin{array}{l}\text { TTF for } \\
\text { bird }\end{array}$ & $\begin{array}{l}\text { predicted } \\
\text { Se in bird } \\
\text { egg } \\
(\mu g / g, d w)\end{array}$ & $\begin{array}{l}\text { observed Se } \\
\text { in bird egg } \\
(\mu \mathrm{g} / \mathrm{g}, \mathrm{dw})\end{array}$ & $\begin{array}{l}\text { species and } \\
\text { number of } \\
\text { samples }\end{array}$ \\
\hline Lower SDC & $\begin{array}{c}\text { sediment>invertebrate> } \\
\text { avocet }\end{array}$ & $\begin{array}{l}\text { corixid, crayfish, snail, } \\
\text { clam }\end{array}$ & $\begin{array}{l}1.2 \\
2.8\end{array}$ & $\begin{array}{l}2.8 \\
2.8\end{array}$ & $\begin{array}{l}3.4 \\
7.8\end{array}$ & 6.2 & $\begin{array}{l}1.8 \\
1.8\end{array}$ & $\begin{array}{c}6.2 \\
14.0\end{array}$ & $\begin{array}{c}2.8 \\
(1.9-3.9)\end{array}$ & avocet (3) \\
\hline Lower SDC & $\begin{array}{c}\text { sediment>invertebrate> } \\
\text { stilt }\end{array}$ & $\begin{array}{c}\text { corixid, crayfish, snail, } \\
\text { clam }\end{array}$ & & 2.8 & & & 1.8 & & $\begin{array}{c}6.9 \\
(3.6-8.7)\end{array}$ & stilt (11) \\
\hline Lower SDC & $\begin{array}{c}\text { sediment>invertebrate> } \\
\text { killdeer }\end{array}$ & $\begin{array}{c}\text { corixid, crayfish, snail, } \\
\text { clam }\end{array}$ & & 2.8 & & & 1.8 & & $\begin{array}{c}9.5 \\
(9.1-9.9)\end{array}$ & killdeer (2) \\
\hline Lower SDC & $\begin{array}{c}\text { sediment>invertebrate> } \\
\text { grebe }\end{array}$ & $\begin{array}{c}\text { corixid, crayfish, snail, } \\
\text { clam }\end{array}$ & & 2.8 & & & 1.8 & & 5.8 & $\begin{array}{l}\text { pied-billed } \\
\text { grebe (1) }\end{array}$ \\
\hline Lower SDC & $\begin{array}{c}\text { sediment>invertebrate> } \\
\text { coot }\end{array}$ & $\begin{array}{c}\text { corixid, crayfish, snail, } \\
\text { clam }\end{array}$ & & 2.8 & & & 1.8 & & 5.2 & $\operatorname{coot}(1)$ \\
\hline IRWD wetlands & $\begin{array}{c}\text { sediment>invertebrate> } \\
\text { avocet }\end{array}$ & $\begin{array}{l}\text { midge, corixid, } \\
\text { dragonfly }\end{array}$ & $\begin{array}{l}3.7 \\
5.3\end{array}$ & 2.8 & $\begin{array}{l}10.4 \\
14.8 \\
\end{array}$ & 10.9 & 1.8 & $\begin{array}{l}18.7 \\
26.6 \\
\end{array}$ & $\begin{array}{c}6.4 \\
(2-17.2) \\
\end{array}$ & avocet (8) \\
\hline IRWD wetlands & $\begin{array}{c}\text { sediment> invertebrate> } \\
\text { stilt }\end{array}$ & $\begin{array}{l}\text { zooplankton, midge, } \\
\text { corixid, snail, crayfish, } \\
\text { dragonfly, clam }\end{array}$ & & 2.8 & & & 1.8 & & $\begin{array}{c}5 \\
(3-9.8)\end{array}$ & stilt (4) \\
\hline IRWD wetlands & $\begin{array}{c}\text { sediment> invertebrate> } \\
\text { mallard }\end{array}$ & $\begin{array}{l}\text { zooplankton, midge, } \\
\text { corixid, snail, crayfish, } \\
\text { dragonfly, clam }\end{array}$ & & 2.8 & & & 1.8 & & $\begin{array}{c}6.2 \\
(4-7)\end{array}$ & mallard (4) \\
\hline IRWD wetlands & $\begin{array}{c}\text { sediment> invertebrate> } \\
\text { killdeer }\end{array}$ & $\begin{array}{l}\text { zooplankton, midge, } \\
\text { corixid, snail, crayfish, } \\
\text { dragonfly, clam }\end{array}$ & & 2.8 & & & 1.8 & & $\begin{array}{c}4.8 \\
(2.6-7.1)\end{array}$ & killdeer (2) \\
\hline UCI wetlands & $\begin{array}{c}\text { sediment> invertebrate> } \\
\text { coot }\end{array}$ & dragonfly & 2.2 & 2.8 & 6.2 & 5.6 & 1.8 & 11.2 & $\begin{array}{c}2.7 \\
(1.9-4.5) \\
\end{array}$ & $\operatorname{coot}(9)$ \\
\hline UCI wetlands & $\begin{array}{c}\text { sediment> invertebrate> } \\
\text { avocet }\end{array}$ & dragonfly & & 2.8 & & & 1.8 & & $\begin{array}{c}5.1 \\
(3.3-11)\end{array}$ & avocet (5) \\
\hline UCI wetlands & $\begin{array}{c}\text { sediment> invertebrate> } \\
\text { grebe }\end{array}$ & dragonfly & & 2.8 & & & 1.8 & & $\begin{array}{c}6.2 \\
(4-11) \\
\end{array}$ & $\begin{array}{l}\text { pied-billed } \\
\text { grebe (4) }\end{array}$ \\
\hline
\end{tabular}


Table 27. Model validation for watershed showing (1) predicted and observed fish Se concentrations and (2) predicted and observed bird egg Se concentrations. [ $\mathrm{d} w=$ dry weight; $n=$ number of samples.]

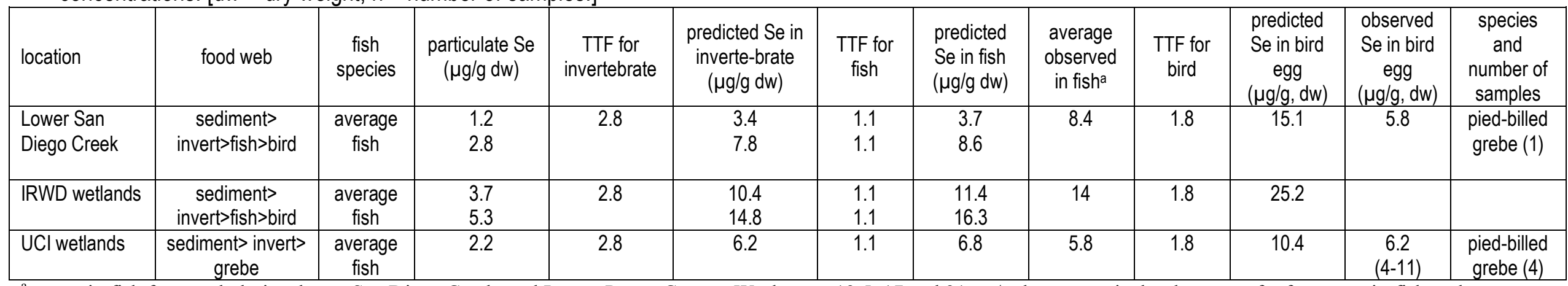

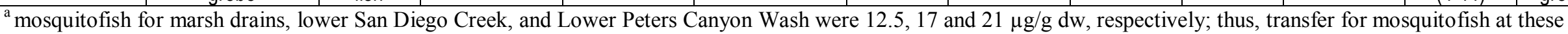
sites are underestimated by a TTF of 1.1 (see table 11 for range of TTFs for mosquitofish) 
Table 28. Model validation for watershed showing predicted and observed bird egg Se concentrations. [ $d w=d r y$ weight; $n=$ number of samples.]

\begin{tabular}{|c|c|c|c|c|c|c|c|}
\hline location & food web & $\begin{array}{c}\text { Se in fish } \\
(\mu \mathrm{g} / \mathrm{g}, \mathrm{wb}, \mathrm{dw})\end{array}$ & fish species & $\begin{array}{l}\text { TTF for } \\
\text { bird }\end{array}$ & $\begin{array}{l}\text { predicted Se in bird } \\
\text { egg }(\mu \mathrm{g} / \mathrm{g}, \mathrm{dw})\end{array}$ & $\begin{array}{l}\text { observed Se in } \\
\text { bird egg } \\
(\mu \mathrm{g} / \mathrm{g}, \mathrm{dw})\end{array}$ & $\begin{array}{l}\text { species and } \\
\text { number of bird } \\
\text { egg samples }\end{array}$ \\
\hline Upper SDC and PCW & sediment>invert>fish $>$ bird & 5.8 & mixed fish & 1.8 & 10.4 & & \\
\hline Marsh drains & sediment>invert>fish>bird & 12.5 & mosquitofish & 1.8 & 22.5 & & \\
\hline Lower SDC & sediment>invert>fish $>$ bird & 7.8 & $\begin{array}{l}\text { bluegill, common carp, fathead } \\
\text { minnow, red shiner, largemouth bass, } \\
\text { black crappie, white catfish, mixed fish }\end{array}$ & 1.8 & 14.0 & 5.8 & $\begin{array}{l}\text { pied-billed } \\
\text { grebe (1) }\end{array}$ \\
\hline Lower SDC & sediment>invert>fish>bird & 17 & mosquitofish & 1.8 & 30.6 & & \\
\hline Lower PCW & sediment>invert>fish>bird & 6.4 & fathead minnow, red shiner & 1.8 & 11.5 & & \\
\hline Lower PCW & sediment>invert>fish $>$ bird & 21 & mosquitofish $(12.1 ; 29.9)$ & 1.8 & 37.8 & & \\
\hline IRWD wetlands & sediment>invert>fish>bird & 19.3 & dead carp (filet) & 1.8 & 34.7 & & \\
\hline IRWD wetlands & sediment>invert>fish>bird & 13 & mixed fish & 1.8 & 23.4 & & \\
\hline IRWD wetlands & sediment>invert>fish>bird & 10.1 & mosquitofish $(2.3 ; 15.3)$ & 1.8 & 18.2 & & \\
\hline $\mathrm{UCl}$ wetlands & sediment>invert>fish>bird & 5.8 & mosquitofish & 1.8 & 10.4 & $6.2(4.0-11)$ & $\begin{array}{l}\text { pied-billed } \\
\text { grebe (4) }\end{array}$ \\
\hline
\end{tabular}




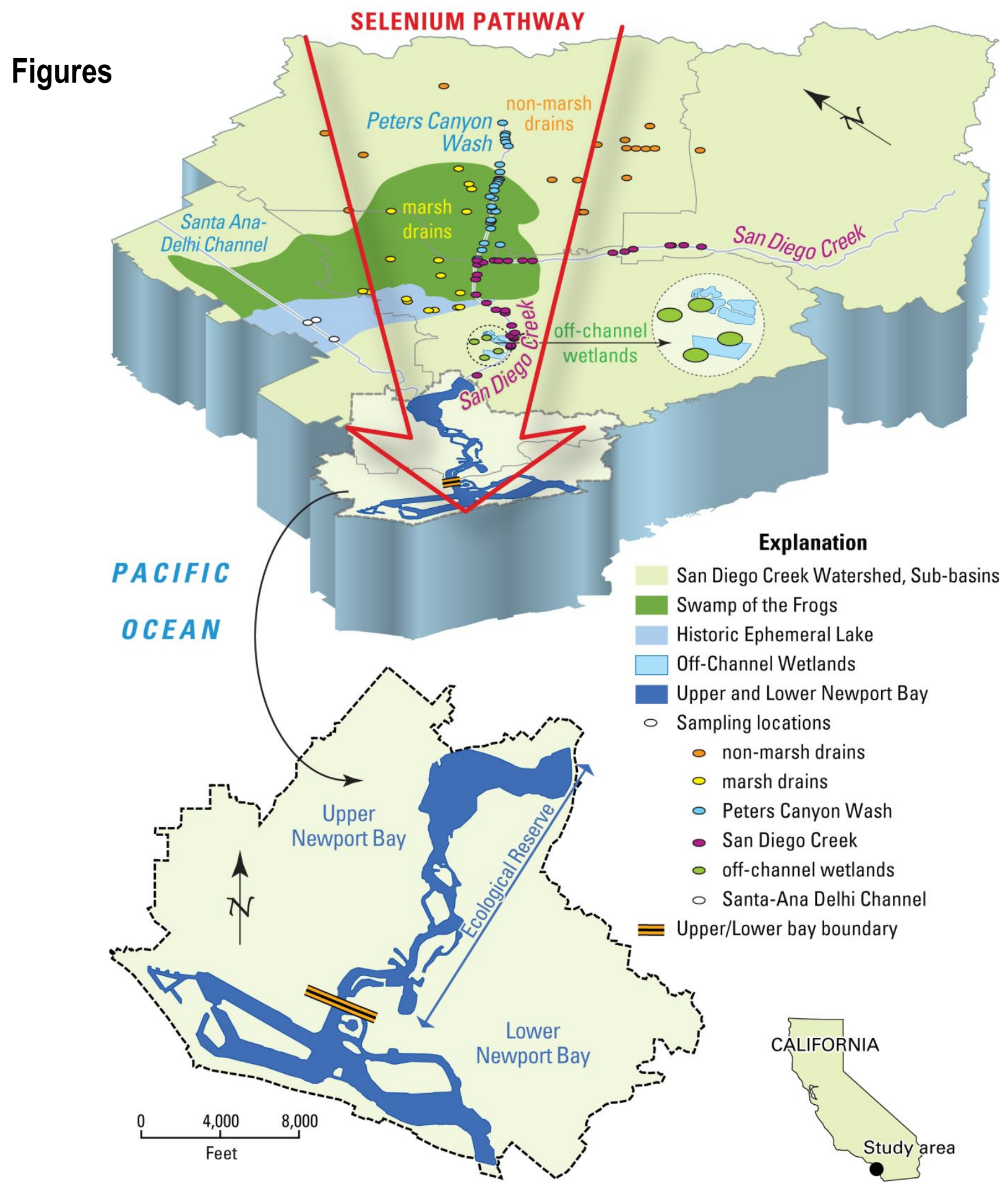

Figure 1. Schematic block diagram of the San Diego Creek watershed and Newport Bay highlighting assessment areas and Se pathway. Map enlargement shows Upper and Lower Newport Bay. 


\section{San Diego Creek Selenium Model}

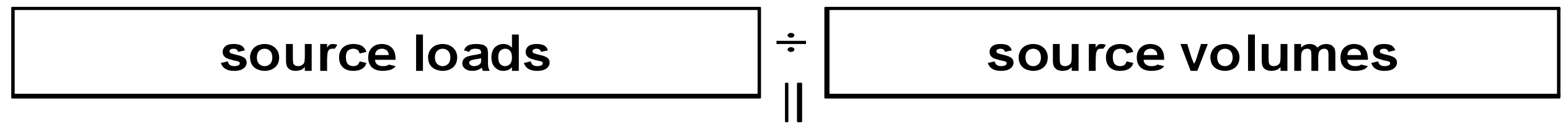

\section{concentration in drains, creeks, wetlands, and at mouth of estuary: dissolved species (selenate; selenite; organo-Se)}

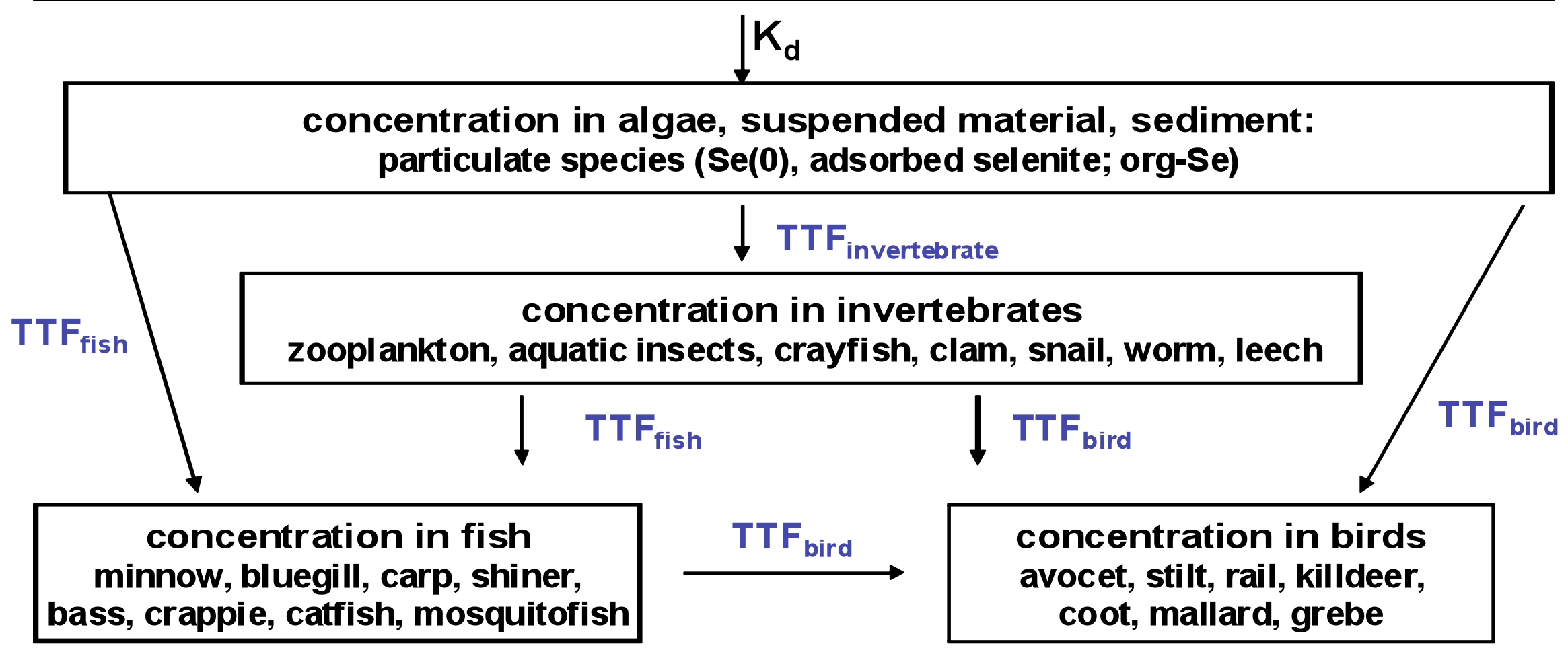

Figure 2. Conceptual model for the San Diego Creek watershed illustrating linked factors that determine the effects of Se on ecosystems. 


\section{Upper Newport Bay Selenium Model}

\section{watershed source loads}
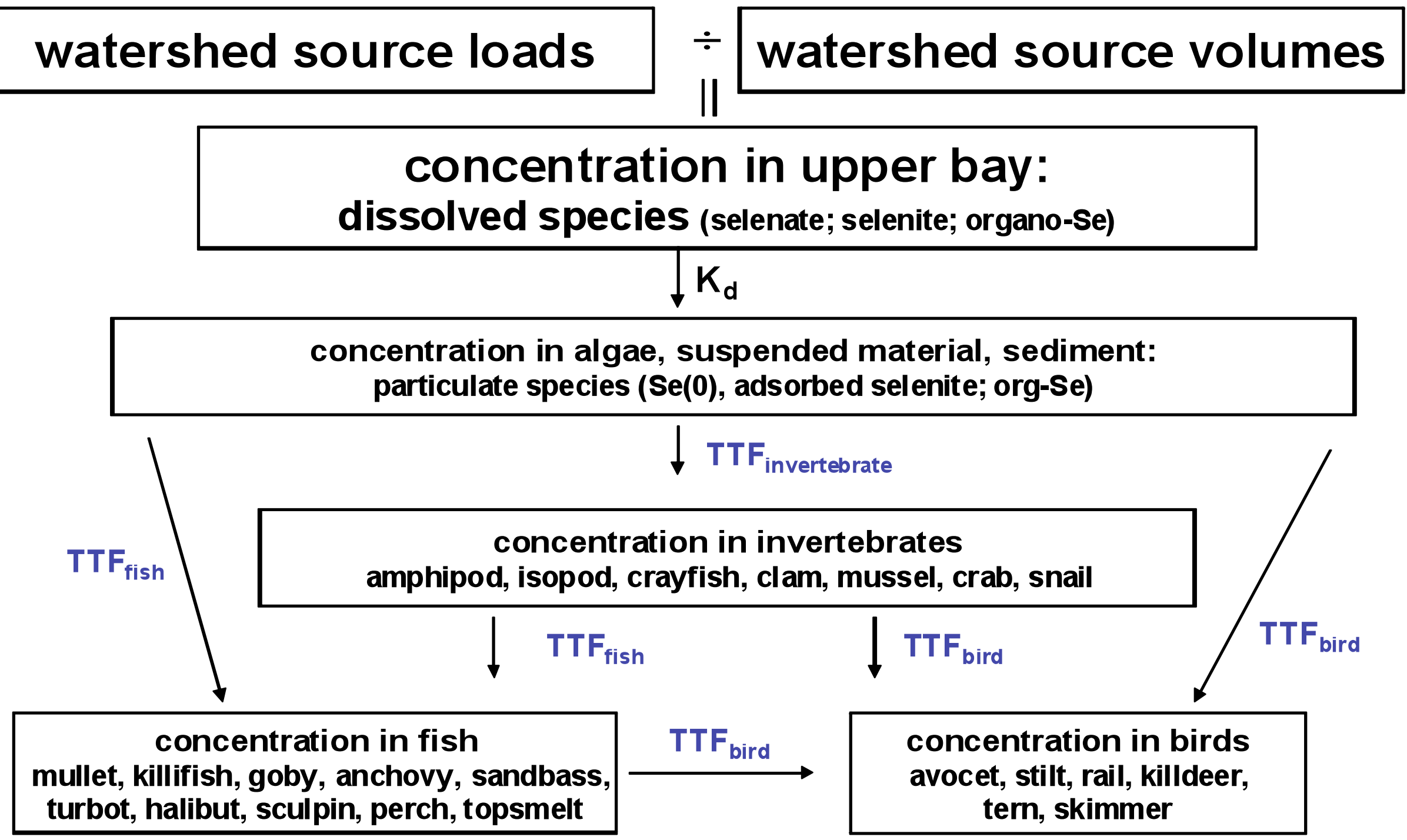


\section{Lower Newport Bay Selenium Model}
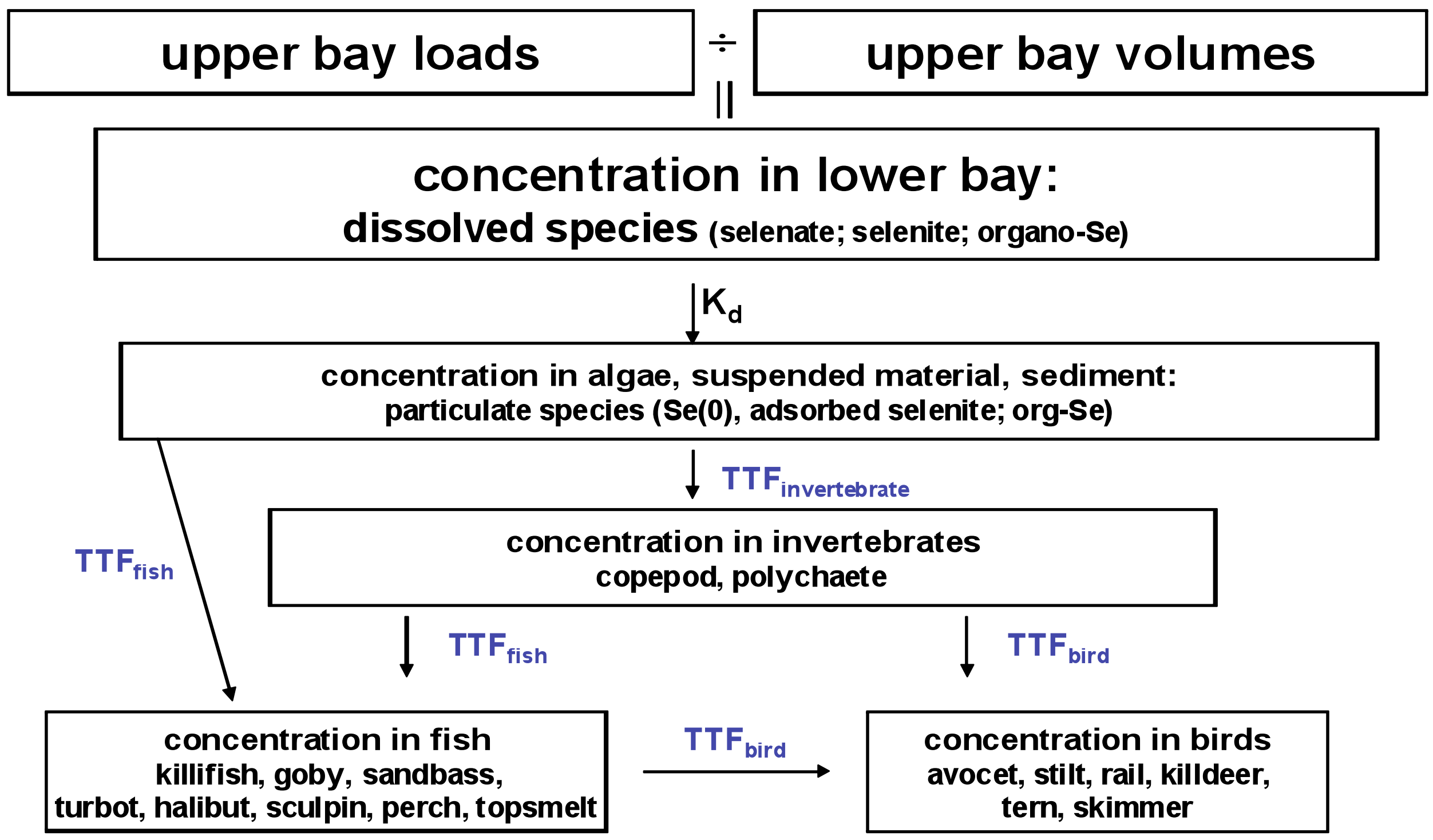


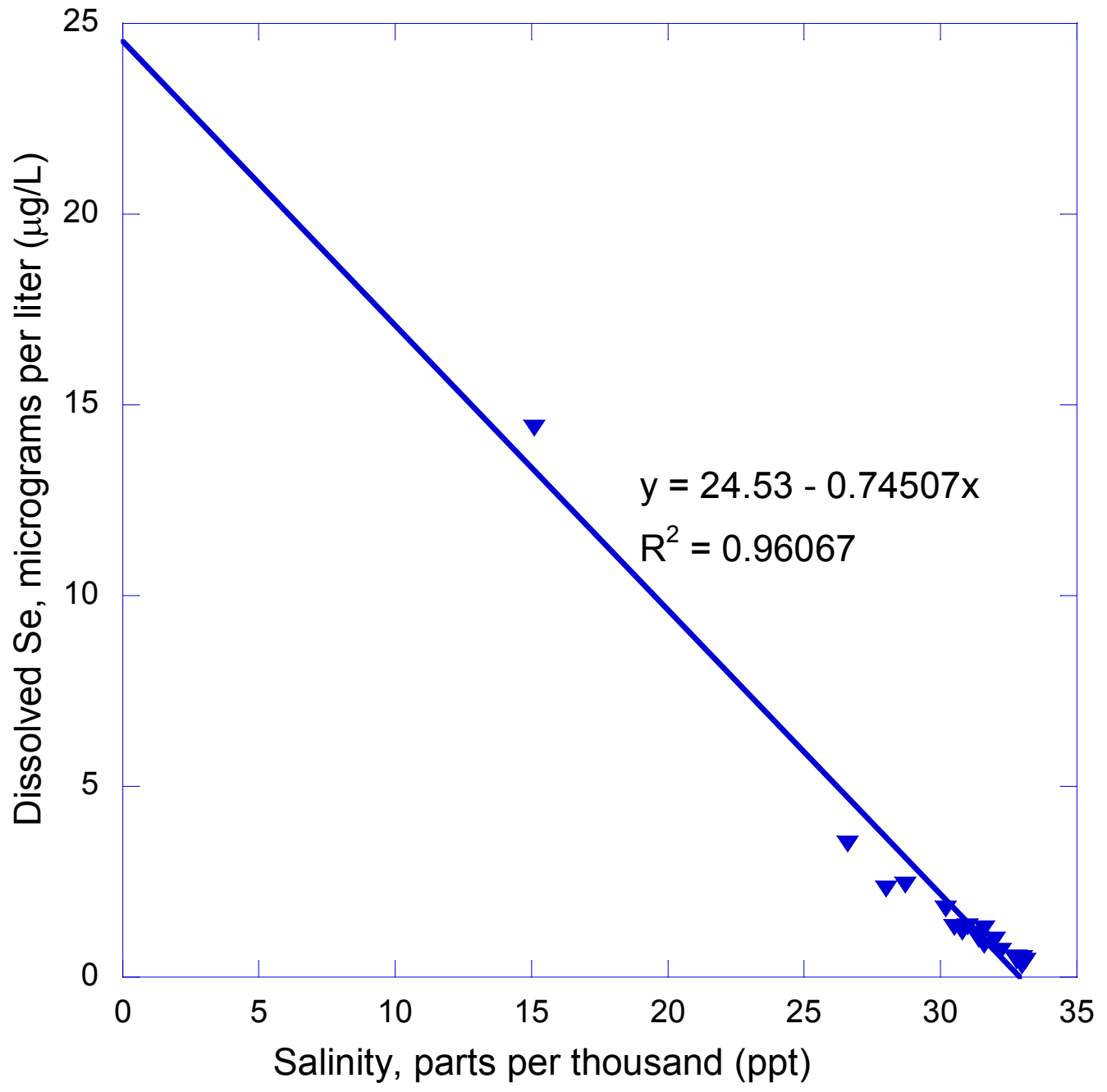

Figure 5. Extrapolation of dissolved Se to $0 \mathrm{ppt}$. Data from transect of the Upper Newport Bay from near the mouth of San Diego Creek into the upper bay (CH2M Hill, 2008a). 